\title{
THE ACTION FOR ALIENATION OF AFFECTIONS
}

\section{ROBERT C. BROWN †}

The most important legal action given for the purpose of protecting marital relations from unjustifiable interference by outsiders is what is known as the action for alienation of affections. This action has its ultimate purpose and its substantial justification, if any, in the interest of the public in the protection from intentional and unjustifiable interference with the stability of the home. It is the purpose of this paper to examine some of the outstanding features of this somewhat unique form of action.

Despite the name which is universally given to this action, it is almost unanimously agreed that the gist of it is not the loss of affections but rather the loss of consortium ${ }^{2}$ - a concept of very much broader content. ${ }^{2}$ Consortium includes at least the sole right to sexual relationship and society and companionship of the spouse as well as affection. ${ }^{3}$ Since the action protects all aspects of the marital consortium it may be maintained although no pecuniary loss be shown ${ }^{4}$ nor need any actual loss of service or support be proved. ${ }^{\overline{5}}$ In fact, the loss of affection, far from being the gist of the action, has sometimes been held merely to aggravate damages in the case of loss of consortium in other respects. ${ }^{6}$ Consortium is a property right, and it would seem to follow that the action for alienation of affections is to be treated as one for a tort to property ; $^{\top}$ even though, as is the case with the action of seduction at common law, the damages are based primarily upon personal injuries to the plaintiff.

† A.B. I9I4, Wesleyan University; LL. B. I9I7, S. J.D. I930, Harvard University; Professor of Law, Indiana University. Author of Reduction of Tax Exemptions by Reasor of Receipt of Tax-Exempt Income (1932) 80 U. OF PA. L. Rev. 534; State Taxation of Interstate Commerce and Federal and State Taxation in Intergovernmental Relations-1930-1932 (1933) 8I U. of PA. L. REv. 247; and contributor to other legal periodicals.

${ }^{x}$ Winsmore y. Greenback, Willes 577 (Eng. I745) (probably the earliest case) ; Boland v. Stanley, 88 Ark. 562, II5 S. W. I63 (I909); Jenness v. Simpson, 84 Vt. 127, 78 Atl. 886 (I9IX) ; Valentine v. Pollak, 95 Conn. 556, III Atl. 869 (I920); Lane v. Dunning, I86 Ky. 797, 218 S. W. 269 (1920); Brown v. Brown, I04 Okla. 206, 230 Pac. 853 (rg24); Anderson v. McGill Club, 5I Nev. I6, 266 Pac. 913 (Ig28) ; Riggs v. Smith, 52 Idaho 43, II P. (2d) $35^{8}$ (1932).

${ }^{2}$ Rott v. Goehring, 33 N. D. 413, 557 N. W. 294 (rgr6).

- Bigaouette v. Paulet, I34 Mass. I23 (I883).

4 Adams v. Main, 3 Ind. App. 232, 29 N. E. 792 (189I).

${ }^{\circ}$ Gregg v. Gregg, 37 Ind. App. 210, 75 N. E. 674 (1905).

- Evans v. O'Connor, I74 Mass. 287, 54 N. E. 557 (1899) ; Dodge v. Rush, 28 App. D. C. 149 (I906).

7 Warren v. Warren, 89 Mich. I23, 50 N. W. 842 (I89I); Crane v. Ketcham, 83 N. J. I. 327,84 Atl. I052 (1912). But see Howard v. Lunaburg, I92 Wis. 507, 213 N. W. 301 (I927). In Allard v. LaPiain, I47 Wash. 497, 266 Pac. 688 (I928), it was held that a judgment against a bankrupt in another state for alienation of the affections of the plaintiff's husband was not discharged by the adjudication. 
There are one or two authorities which seem to take the position that the gist of the action is loss of affection. 8 Even such authorities, however, take cognizance of other sorts of injuries to the consortium so that the results are not really distinct from those of the jurisdictions which regard the loss of consortium as the real point of the action.

A more serious problem arises in defining the relationship of this action with that for criminal conversation. The two forms of action are obviously closely connected and may be joined. ${ }^{9}$ Proof of loss of affection in the strict sense will aggravate the damages in a count for criminal conversation; $;^{10}$ and conversely, proof of adultery will aggravate the damages in a count for alienation of affections. ${ }^{11}$ Proof of adultery is sufficient to sustain an action for criminal conversation, but it is insufficient to sustain an action for alienation of affections since it is conceivable (though undoubtedly unusual) that companionship or affection will be undiminished even though one of the spouses has been led into adultery with an outsider..$^{12}$

It is not always easy to determine which of these actions is involved. It is sometimes held that an allegation of adultery between the alienated spouse and the defendant involves an action for criminal conversation as well as alienation of affections; ${ }^{13}$ but where the action is avowedly for criminal conversation, an allegation of actual alienation of affections is normally treated not as involving a separate count but merely for the purpose of aggravating damages. ${ }^{14}$ Indeed, it is rather more usual to treat an allegation of adultery in an alienation action as incidental to the action rather than as involving a separate count for criminal conversation. ${ }^{15}$ The adultery may be involved not merely as aggravating damages but may itself be one of the methods used to destroy the affections of the alienated spouse and to effect a separation of the spouses. ${ }^{16}$

It is obvious therefore that the gist of an action for criminal conversation is adultery, and that this is certainly not the primary basis of an action for alienation of affections. In neither case, however, is the action, in form

${ }^{8}$ Annarina v. Boland, I36 Md. 365 , III Atl. 84 (1920) ; Johnson v. Richards, 50 Idaho I50, 294 Pac. 507 (I930).

Dodge v. Rush, supra note 6; Merritt v. Cravens, I68 Ky. I55, I8I S. W. 970 (I9I6); Murrell v. Culver, I4I Md. 349, II8 Atl. 803 (I922) ; Labrie v. Midwood, 273 Mass. 578, I74 N. E. 2I4 (I93I).

${ }^{10}$ Sullivan v. Valiquette, 66 Colo. 170 , I80 Pac. 9I (I9I9); Hargraves v. Ballou, 47 R. I. I86, I3I Atl. 643 (1926). See also Bigaouette v. Paulet, supra note 3.

i1 Bariow v. Barnes, I72 Cal. 98, I55. Pac. 457 (I9I6); Watkins v. Lord, 31 Idaho 352, I7I Pac. II33 (Igr8).

${ }_{12}$ Valentine v. Pollak, supra note I. (1927).

${ }^{13}$ Valentine v. Pollak, supra note I; Bradbury v. Brooks, 82 Colo. 133, 257 Pac. 359

${ }_{14}$ See cases cited sipra note Io.

${ }^{15}$ Hart v. Knapp, 76 Conn. I35, 55 At1. Iozr (1903) ; Joseph v. Naylor, 257 Pa. 56r, Ior At1. 846 (rgi7); Rhodes v. Meloy, 289 S. W. 159 (Tex. Civ. App. 1926); Ireland v. Ward, 51 Ore. 102, 93 Pac. 932 (1908); Hutchinson v. Taylor, 129 Cal. App. 369 , 18 P. (2d) 722 (1933).

${ }^{10}$ Deming v. Leising, 214 App. Div. 398, 212 N. Y. Supp. 213 (I925). 
at least, against the spouse of the plaintiff; accordingly condonation will not bar an action even for criminal conversation. ${ }^{17}$ Nor will the plaintiff in a criminal conversation or alienation action be barred by his own neglect to safeguard his spouse from the seductions of the defendant. ${ }^{18}$ It has been held that there is no distinction between the two kinds of action, that both alienation and criminal conversation actions are based upon loss of consortium. ${ }^{19}$ This is true in a sense, except that alienation actions involve a much larger concept of consortium than is the case with criminal conversation actions. The real difference between the two seems to be that in criminal conversation actions the loss of consortium is conclusively presumed from the mere proof of adultery; whereas in actions for alienation of affections the actual injury to the affections or at least some loss of companionship of the alienated spouse (though not necessarily amounting to an actual separation) must appear. ${ }^{20}$ The line between the two actions is necessarily somewhat indistinct, but criminal conversation is the more definite action. Its defect, which the action for alienation of affections corrects, is that a criminal conversation action furnishes no adequate protection against many serious injuries to the marital relationship which may not involve adultery, or if they do involve that offense, also involve an injury to consortium in other aspects.

\section{The Right to Maintain the Action}

The distinct weight of authority permits the maintenance of an action for alienation of affections in the strictest sense by the wronged spouse, or, at least, very few jurisdictions seem to doubt the power of the husband to maintain the action against one who alienates the affections of his wife. Some American jurisdictions have sought to deny, or at least to limit the action, but they have not proceeded very far in this direction.

The leading state which denies an action for alienation of affections is Massachusetts. In that jurisdiction probably the leading case is Tasker $v$. Stanley, ${ }^{21}$ where a husband was denied a right of action against another man who had not merely alienated the affections of the plaintiff's wife but had persuaded her to desert him. The reasoning of the court is based upon two general propositions: first, that no harm would have been done by the plaintiff's persuasion had it not been for the affirmative act of the wife herself. and, secondly, that under modern statutes emancipating married

${ }^{17}$ Sikes v. Tippins, 85 Ga. 23I, II S. E. 662 (I890).

${ }^{18}$ Alex v. Strickland, III Okla. 267, 239 Pac. 596 (I925).

${ }^{10}$ Miller v. Pearce, 86 Vt. 322, 85 Atl. 620 (r9I3). See also Hart v. Knapp, supra note 15.

${ }^{20}$ Alex v. Strickland, supra note I8. See also Disch v. Closset, II8 Ore. III, 244 Pac. 7 I (I926). C $f$. (rgI8) 3 CORN. L. Q. 228 .

${ }_{2}{ }_{53}$ Mass. 148,26 N. E. 4I7 (I89I). See also Geromini v. Brunelle, 2I4 Mass. 492 , 102 N. E. 67 (I9I3). 
women from the control of their husbands, it is not very seriously wrong for a wife to leave her husband.

It is submitted that both of these reasons are absurd. If the first is to be applied it would seem to follow that no person can be put under criminal liability if he confines his activities to urging someone else to actually commit the crime, since in this case a crime would not have been committed had it not been for the independent act of the person thus persuaded. And if the court's construction of the emancipation statutes is correct their primary purpose, or its effect, is to break up homes! Certainly no one would seriously argue for this proposition.

It is not contended, of course, that the unsoundness of the result of Tasker $v$. Stanley is entirely proved by this attack upon its reasoning. The question of policy must be left for later consideration. In any event, the Massachusetts authorities have adhered to their position that alienation of affections is not of itself a ground for action in that state, ${ }^{22}$ though if other grounds such as adultery appear the alienation of affections will aggravate damages. $^{23}$ Furthermore, the courts have gone a long way in stretching the facts so as to find that infinitesimal amount of activity beyond alienation which will give a cause of action. ${ }^{24}$ Thus a mere showing of ill-will to the plaintiff on the part of the defendant will justify an action on this general basis. ${ }^{25}$ This does not prove that Massachusetts is wrong in declining to permit an action merely for alienation for affections, although it raises grave doubts on that point. ${ }^{26}$

A few other states have indicated an unwillingness to permit this action. Of these the one which has taken the most definite position is Louisiana, ${ }^{27}$ but Alabama ${ }^{28}$ and California ${ }^{29}$ have also indicated some

$\approx$ Houghton v. Rice, I74 Mass. 366,54 N. E. 843 (1899) ; Neville v. Gile, I74 Mass. 305, 54 N. E. 841 (I899) ; Negus v. Foot, 228 Mass. 375, II7 N. E. 35 I (I9I7) ; Longe v. Saunders, 246 Mass. 159 , I40 N. E. $74 \mathrm{I}$ (1923). (I92I).

${ }^{2}$ Labrie v. NLidwood, supra note 9; Gahagan v. Church, 239 Mass. 558, I32 N. E. 357

${ }_{24}$ Sherry v. Moore, 265 Mass. 189, I63 N. E. 906 (I928). Cf. decision on previous appeal of this case in $25^{8}$ Mass. 420, I55 N. E. 44I (1927); Bradstreet v. Wallace, 254 Mass. 509 , I 50 N. E. 405 (I926).

= Lanigan v. Lanigan, 222 Mass. 198, r1o N. E. 285 (r9I5) ; Falk v. Falk, 279 Mass. 530, I8I N. E. 7I5 (I932). In both of these cases, the defendants were sufficiently close relatives of the alienated spouse so that, under principles hereafter discussed, they probably could not be held in any jurisdiction in the absence of the very malice upon which the court relied as distinguishing them from Tasker v. Stanley, I53 Mass. 148, 26 N. E. 4I7 (I89r).

${ }^{\circ}$ See, however, notes criticising this Massachusetts view in (1924) 9 CoRN. L. Q. 200; and (Ig28) 22 ILL. L. Rev. 557.

$\approx$ It was held in Hennessey v. Wahlig, r55 La. 465,99 So. 405 (1924), that an action for alienation of affections would lie under the Louisiana Code. But this decision was overruled by Moulin v. Monteleone, I65 La. I69, II5 So. 447 (I927), on the ground that an alienation action is solely for punitive damages, and such are not allowed in Louisiana. One may concur in the court's condemnation of punitive damages, and yet disagree with the ruling that no alienation action will lie. See (I928) I4 VA. L. Rev. 582.

${ }^{2}$ Veal v. Conn, 215 Ala. 90, 109 So. 754 (1926).

m See Mohn v. Tingley, I9I Cal. 470, 217 Pac. 733 (1923). 
hostility. However, all these states, and especially the two last named, go at least as far as Massachusetts in sustaining what are substantially alienation actions. $^{30}$ The result would seem to be that the few limitations upon the substantive right to maintain this action are of trifling practical importance.

One requirement for sustaining the action is fairly obvious-that is that the plaintiff and the alienated spouse be married at the time of the defendant's acts complained of. But a marriage voidable because of the lack of statutory age by one of the parties is nevertheless sufficient; ${ }^{31}$ so is a common law marriage, ${ }^{32}$ even though the spouses had previously been ceremonially married and divorced. ${ }^{33}$

But there remains what was until recently the most serious problem: whether a wife could maintain the action when her husband was the alienated spouse. It is obvious that a wife could not maintain the action at common law, not because of its nature, but because she had no right to maintain any action. In England an attempt was made fairly early to obviate this difficulty by joining the husband himself as a party defendant $;^{34}$ but the effort was not successful.

However, the common law as to husband and wife is no longer in effect in any civilized jurisdiction, and the practical problem soon became to determine whether the ordinary emancipation statutes gave the wife a right to maintain an action for alienation of affections. Probably the leading case giving an affirmative answer to this question is the Indiana case of Hayes $v$. Nowlin, ${ }^{35}$ which presents a full and conclusive argument in favor of this construction of the emancipation statutes. This doctrine has been followed by the overwhelming weight of authority. ${ }^{36}$ The fact that the wife is an infant does not seem to affect her right to maintain the action. ${ }^{3 \pi}$

The reasoning under which this result was reached is that at common law the wife had the same right in the consortium of the husband as he had in hers. Her disability was merely procedural; the right existed but it could not be enforced. The emancipation statutes have removed this disability and have thereby put her in the same position in respect to this action as her 29.

${ }^{*}$ See Woodson v. Bailey, 210 Ala. 568, 98 So. 809 (I924) ; Mohn v. Tingley, supra note

${ }^{21}$ Luke v. Hill, I37 Ga. I59, 73 S. E. 345 (I9Ir).

* Hollinghausen v. Ade, 289 Mo. 362, 233 S. W. 39 (I92I).

Butterfield v. Ennis, I93 Mo. App. 638, 186 S. W. Ir73 (I916).

" See Lynch v. Knight, 9 H. L. Cas. 577 (Eng. 1861).

₹ 129 Ind. 581,29 N. E. 389 (I891).

${ }^{20}$ Among the leading authorities to this effect are Westlake v. Westlake, 34 Ohio St. 62I (I878); Seaver v. Adams, 66 N. H. I42, I9 Atl. 776 (I890) ; Price v. Price, 91 Iowa 693, 60 N. W. 202 (I894); Keen v. Keen, 49 Ore. 362, 90 Pac. I47 (Ig07); Gross v. Gross, 70 W. Va. 317, 73 S. E. 96i (19I2); Weber v. Weber, II3 Ark. 47I, I69 S. W. 318 (I914); Woodson v. Bailey, supra note 30 ; Hoover v. Hoover, I03 Fla. 846 , I38 So. 373 (I931); Sessions v. Parker, I74 Ga. 296, I62 So. 790 (I932).

"Warren v. Warren, supra note 7. 
husband has always been. ${ }^{38}$ Granting that this reasoning is somewhat abstract and theoretical, it seems essentially sound and certainly leads to a desirable result.

Only three jurisdictions have shown any disposition, at least recently, to deny the right of the married woman to maintain this action; and one of those, New Jersey, ${ }^{39}$ changed its result without the aid of any specific statute and now follows the weight of authority. Only Maine and Wisconsin have adhered consistently to the view that general emancipation statutes have not granted a married woman the right to bring such an action.

The Maine court seems to have had almost an obsession on the point, and construed fairly direct and inclusive emancipation statutes as not giving this right to a married woman, although they seemed to give her every other kind of right. ${ }^{ \pm 0}$ The legislature, however, did not share this obsession, and has attempted to give to married women the specific right to maintain the action for alienation of affection. ${ }^{41}$

The Wisconsin court originally had to deal with a less specific emancipation statute, so that it was not compelled to engage in such curious expedients of statutory construction as was the Maine court. Nevertheless the reasoning of the leading case in that state, Duffies $v$. Duffies, ${ }^{42}$ seems hardly more commendable. The court's idea was that it would be impolitic to allow the wife to bring such an action because the husband leads such an active life that he is more likely to be seduced by designing women; that the wife must expect this when she marries him; and accordingly that to permit her to sue for such an evil would lead to overmuch litigation.

To comment upon this alleged reasoning would be impossible without approaching contempt of court. One is encouraged to note however that the court later, after a statute had changed the rule, admitted its own absurdity, saying that the statute did not result in the enormous increased legislation prophesied in the Duffies case. ${ }^{43}$ Even before the statute was passed, the Wisconsin court did much to obviate the effects of its own rule (that the wife could not bring such an action) by holding, somewhat illogically, that

${ }^{3}$ This reasoning is fully set forth in Bennett v. Bennett, II6 N. Y. 584,23 N. E. I7 (1889); Foot v. Card, 58 Conn. I, I8 Atl. 1027 (I889).

${ }^{\infty}$ Sims v. Sims, 79 N. J. L. 577, 76 Atl. 1063 (1910), holding that a wife may maintain an action for the alienation of the affections of her husband, overruling in this respect the contrary decision of Hodge v. Wetzler, 69 N. J. L. 490, 55 At1. 49 (I903).

${ }^{4}$ Farrell v. Farrell, II8 Me. 44I, I08 Atl. 648 (1920) ; Howard v. Howard, 120 Me. 479, II5 Atl. 259 (I92I). See adverse comment on this doctrine, especially as exemplified in the case last cited, in Note (1922) 8 VA. L. REv. 370.

a Wilson v. Wilson, II5 Me. 34I, 98 Atl. 938 (I9I6). But $c f$. Howard v. Howard, supra note 40 , holding that since the statute gives the right to the wife only to sue another woman, she has still no right to maintain the action against a male defendant.

76 Wis. 374,45 N. W. 522 (1890).

4 Wait v. Pierce, I9I Wis. 202,209 N. W. 475 (1926). The statute does not give to the wife the right to sue her husband for his own alienation, and so he should not be joined as a party defendant. White v. White, 140 Wis. 538,122 N. W. 105I (I909). 
the wife could bring an action where there were several defendants who had conspired to bring about the alienation of the husband's affections. ${ }^{44}$

The problem of the wife's right to sue is therefore no longer of practical consequence. $^{45}$ The only remaining problem results from the doctrine of community property where that doctrine is accepted. Obviously if the damages become community property, which is usually under the husband's management, the power of the wife to sue is not of substantial advantage to her. There are few decisions ${ }^{46}$ and they appear to have dodged the point, although under some community property statutes the problem appears to be somewhat troublesome. ${ }^{47}$ In some way or other, the result will probably be reached that the amount recovered belongs to the wife's separate estate.

\section{Defenses}

The most obvious defense would be that the defendant was not responsible for the alienation of affections of the plaintiff's spouse. Consequently such responsibility must be proved by the plaintiff as a part of his case. ${ }^{48}$ The defendant's active and successful interference in the marital relations must be shown. ${ }^{49}$ Furthermore, the plaintiff must show that the defendant was the actual cause of the alienation and that the alienated spouse did not act of his own volition.50 If the defendant's activities, though resulting in alienation, were justified by his business relations with the alienated spouse, he is not liable. ${ }^{51}$

A rather special application of this doctrine frequently appears where the wife is the plaintiff and is suing another woman for the alienation of affections of her husband. Here it is frequently held that the burden on the plaintiff is especially heavy since she must prove that the defendant was active in persuading the alienated husband to withdraw his affections and companionship from his wife, rather than, as is more frequently the case, a mere passive recipient of his affections. ${ }^{52}$ If the alienated husband is the

"Randall v. Lanstorf, I26 Wis. 147 , I05 N. W. 663 (1905).

4 Except possibly in Maine. See supra note 4I.

${ }^{4}$ Beach v. Brown, 20 Wash. 266, 55 Pac. 46 (1898) ; Smith v. Womack, 27I S. W. 209 (Tex. Civ. App. I925); Norris v. Stoneham, 46 S. W. (2d) 363 (Tex. Civ. App. 1932).

"See Note (I932) Io TEx. L. REv. 468.

$\$ 8$ Young v. Young, 8 Wash. 8r, 35 Pac. 592 (1894); Scott v. O'Brien, 129 Ky. x, I1o S. W. 260 (I908); Bourne v. Bourne, 43 Cal. App. 516, r85 Pac. 489 (I9I9); Kadow v. Kadow, I95 Wis. 650,219 N. W. 275 (1928).

${ }^{4}$ Hanor v. Housel, I28 App. Div. 80I, I13 N. Y. Supp. I63 (I908) ; Workman v. Workman, 43 Ind. App. 382,85 N. E. 997 (1909).

"Eo Eklund v. Hackett, I06 Wash. 287, I79 Pac. 803 (I9I9) ; Curtis v. Miller, 269 Pa. 509, I12 Atl. 747 (I92I). The defendant is obviously not liable if the separation was the plaintiff's own fault. Annarina v. Boland, supra note 8; Oyler v. Fenner, 263 Mich. II9, $248 \mathrm{~N}$. W. 567 (I933).

${ }_{51}$ Jennings v. Cooper, 230 S. W. 325 (Mo. App. I92r).

${ }^{\circ}$ Waldron v. Waldron, 45 Fed. 3I5 (C. C. N. D. Ill. 1890 ), rev'd on other grounds 156 U. S. 361 , I5 Sup. Ct. 383 (I895); Loper v. Askin, I78 App. Div. I63, I64 N. Y. Supp. I036 (I9I7) ; Stewart v. Hagerty, 25I Pa. 603, 96 Atl. I099 (I9I6); Woodson v. Bailey, silpra note 30 . 
pursuer rather than the pursued, the "other woman" is, of course, not liable, at least in the case of alienation in the strict sense; it may be somewhat different when adultery is proved. ${ }^{53}$ But a woman defendant will not be excused merely by reason of the fact that the plaintiff's husband was the original aggressor if in fact she subsequently took active steps to alienate him from his wife. ${ }^{54}$

On the other hand, the defendant is never liable unless he acts intentionally. Whatever may be the liability for negligent injuries to consortium, ${ }^{55}$ this action does not have anything to do with them. The leading case on this point is Lillegren v. Burns Detective Agency, ${ }^{56}$ where the defendant was employed by plaintiff (who suspected that his wife was unchaste) to shadow her. The defendant shadowed the wrong woman. As a result, the plaintiff falsely charged his wife with unchastity and she accordingly left him. $\mathrm{He}$ sued the defendant for the alienation of her affections but failed, since the defendant was merely negligent and did not intentionally interfere with the marital relations.

So the defendant will not be held liable for derogatory statements concerning the plaintiff unless it can be shown that the natural and intended effect of such statements was to cause an alienation of affections. ${ }^{5 T}$ Nor will the defendant be held, at least in this form of action, for injurious acts directed against the spouse of the plaintiff, even though the plaintiff's rights of consortium are thus injured, unless it can be shown that such injury was intended. ${ }^{58}$ The rule has its most obvious and perhaps most frequent application where it is shown that the defendant did not know that the alienated spouse was married. ${ }^{59}$ In such cases there can of course be no recovery, since the injury to consortium was obviously not intentional. On the other hand mere lack of ill-will toward the plaintiff is not necessarily a defense; if the defendant's acts were reasonably calculated to cause a substantial loss of consortium to the plaintiff the defendant is liable irrespective of his feelings toward the plaintiff. ${ }^{60}$

"Miller v. Pearce, supra note I9. But the better view is that if the woman defendant though actively seduced by the plaintiff's husband, continues voluntarily to live with him in aduitery, she is liable to the plaintiff. Hart v. Knapp, supra note 15.

${ }^{6}$ Norris v. Stoneham, sitpra note 46 .

$\varpi$ See Feneff v. New York, etc. R. R., 203 Mass. 278,89 N. E. 436 (Igog).

I35 Minn. 60, 160 N. W. 203 (I916). So, a wife will fail in an action against a club which successfully tempted the plaintiff's husband to spend his time (and money) at the gambling table rather than with the plaintiff, as this injury to the plaintiff was incidental and could not be shown to have been intended. Anderson V. McGill Club, supra note $I$.

${ }^{57}$ Lynch v. Knight, supra note 34 .

s Nieberg v. Cohen, 88 Vt. 281, 92 At1. $2 \mathrm{I}_{4}$ (I914) ; Bevers v. Bradstreet, r7o Ark. 650, 280 S. W. 667 (1926). See also Warner v. Miller, I7 Abb. N. C. 22I (N. X. I885).

${ }^{6}$ Loper v. Askin, supra note 52 ; Madison v. Neuburger, 130 Misc. 650, 224 N. Y. Supp. 46r (Ig27); see Bresch v. Wolf, 243 Mich. 638, 220 N. W. 737 (Ig28).

क Eklund v. Hackett, supra note 50; Moelleur v. Moelleur, 55 Mont. 30, 173 Pac. 419 (IgI8) ; Hodge v. Brooks, 153 Ark. 222, 240 S. W. 2 (I922). 
It appears, then, that the intended acts of the defendant must be a cause of the loss of consortium in order that the plaintiff may receive redress, in this sort of action. The problem still remains whether the defendant must be the sole cause. The authorities seem unanimous in answering this question in the negative. It is generally said that he must be the controlling cause, ${ }^{61}$ but if so, he is not excused by other contributory causes, ${ }^{62}$ even the misconduct of the plaintiff himself. ${ }^{63}$ On the other hand a defendant cannot be held liable merely because he had something to do with the alienation; ${ }^{64}$ he must, as just pointed out, be the controlling cause, which would seem to mean a substantial cause.

Where more than one defendant is joined, some of them are apt to make the defense that they were not personally implicated in the acts complained of. If the defendants are charged with conspiring to alienate the affections of the plaintiff's spouse, the plaintiff obviously shows a good cause of action against all defendants unless indeed the plaintiff himself is implicated in the conspiracy. ${ }^{65}$ If the conspiracy is proved, each defendant is liable for the acts of all. ${ }^{66}$ If it is not proved, he may still be liable for his own acts if they are a substantial cause of the alienation of the plaintiff's spouse. ${ }^{67}$

The problem of conspiracy frequently arises where a husband and wife are defendants in an alienation suit. The most usual situation of this sort is where they are the parents of the alienated spouse. Under these circumstances the father often seeks to avoid personal liability by disclaiming liability for the acts of the mother, who is usually the more active party in bringing about the alienation. Of course, if the defendant husband is a conspirator with his wife or others he is liable ${ }^{68}$ but in the absence of such conspiracy he is liable ${ }^{69}$ only where there are still vestiges of a husband's

a Hadley v. Heywood, I2x Mass. 236 (1876) ; Pugsley v. Smyth, 98 Ore. 448, 194 Pac. 686 (I92r) ; Disch v. Closset, supra note 20. In Maahs v. Schultz, 207 Wis. 624, 242 N. W. r95 (1932), it was held reversible error to instruct the jury that the defendant was liable if he was $a$ controlling cause of the alienation; he must be the controlling cause. In Kleber v. Allin, I53 Minn. 433, I90 N. W. 786 (1922), the defendant was held liable if he was the "procuring cause" of the alienation.

${ }^{62}$ Lundstrom v. Nelson, II4 Kan. 324, 2I9 Pac. 509 (I923) ; Rhodes v. Meloy, supra note I5; Sargent v. Robertson, I04 Vt. 4I2, I60 Atl. I82 (I932).

${ }^{e 3}$ Linden v. McClintock, I87 S. W. 82 (Mo. App. I916).

6r Larrabee v. Lynch, ro5 N. J. L. I3, I43 Atl. 742 (I928).

$\approx$ Modica v. Martino, 2II App. Div. 516, 207 N. Y. Supp. 479 (1925).

${ }^{\infty}$ White v. White, supra note 43; Rockwell v. Rockwell, I8I Minn. I3, 23I N. W. 718 (1930) ; see also Randall v. Lanstorf, supra note 44. A release of one person from liability for alienating the affections of the plaintiff's spouse does not release another person similarly liable if he did not conspire with the person released. Henry v. Henry, I92 Iowa 1346, I86 N. W. 639 (I922).

or Ratcliffe v. Walker, I17 Va. 569, 85 S. E. 575 (1915).

${ }^{6}$ McAllister v. McAllister, 72 Colo. 28, 209 Pac. 788 (1922) ; Nelson v. Nelson, 296 Fed. 369 (C. C. A. 2d, 1924).

${ }^{\infty}$ Beem v. Beem, I93 Ind. 48I, I4I N. E. 8I (r923) ; Pooley v. Dutton, I65 Iowa 745, I47 N. W. I54 (I9I4); Claxton v. Pool, I97 S. W. 349 (Mo. I9I7) ; Burnett v. Cobb, 262 S. W. 826 (Tex. Civ. App. Ig24). Cf. Boland v. Stanley, stupra note I. 
liability for the torts of his wife. ${ }^{70}$ It is generally held that mere unfriendliness to the plaintiff and even actual unkindness to the plaintiff will not show that the father-in-law entered into the conspiracy. ${ }^{71}$ It has even been held that active approval of the activities of his wife does not show that the male defendant conspired with her $;^{72}$ but it is certain that this comes very close to entering the conspiracy and is likely to subject the unduly fond father to liability to his son or daughter-in-law. ${ }^{73}$

The defense most frequently used is that based upon the privilege which is given to parents and other close relatives of the alienated spouse. Under this doctrine many activities of the relatives which would ordinarily subject them to legal liability are held to be justified.

The privilege is perhaps most often applied in the case of parents, but it should apply also to other near relatives. ${ }^{74}$ Thus brothers ${ }^{75}$ and sisters ${ }^{76}$ of the alienated spouse are entitled to the same presumption in their favor. The same applies to other blood relatives, ${ }^{77}$ provided the relationship is not too remote. ${ }^{78}$ It may include others than blood relatives. Thus, a guardian is obviously entitled to the presumption, as he is essentially in a position of a parent. $^{79}$ Other persons in a relationship to the alienated spouse which is in fact close though not one of blood, such as step-parents ${ }^{80}$ and brothers- and sisters-in-law, ${ }^{81}$ are also ordinarily entitled to take advantage of this privilege. In one old and rather peculiar case ${ }^{82}$ a son-in-law was held entitled to the privilege as a defense for the alleged alienation of the affections of his mother-in-law. In another case it was indicated that a former fiancé of the

${ }^{\pi 0}$ Holtz v. Dick, 42 Ohio St. 23 (I884). In Burnett v. Cobb, supra note 69 , it was held that the husband of the female defendant who had "carried on" with the plaintiff's husband should not be held to his common law liability for his wife's torts, in view of the fact that he himself, as well as the plaintiff, was a victim of this tort.

7 Heisler v. Heisler, I5I Iowa 503, I3I N. W. 676 (I9II) ; Caplan v. Caplan, 83 N. H. 3I8, I42 Atl. I2I (I928).

${ }^{72}$ Caplan v. Caplan, supra note 7r.

73 Okrent v. Raffa, $206 \mathrm{Ky}$. 2II, 266 S. W. I079 (I924).

"See Note Ann. Cas. I9I7E IO27.

$\pi$ Glass v. Bennett, 89 Tenn. 478 , I4 S. W. 1085 (I89I) ; Allen v. Forsythe, I6o Mo. App. 262, I42 S. W. 820 (I9I2); Baird v. Carle, I57 Wis. 565, I47 N. W. 834 (I9I4); Ratcliffe v. Walker, supra note 67; Surbeck v. Surbeck, 208 S. W. 645 (Mo. App. IgI8) ; Harlow v. Harlow, I52 Va. 910, 143 S. E. 720 (I928); Oyler v. Fenner, supra note 50; see Cole v. Johnson, I03 Ore. 3I9, 205 Pac. 282 (I922).

${ }_{73}$ Powell v. Benthall, I36 N. C. I45, 48 S. E. 598 (1904); Allen v. Forsythe; Harlow v. Harlow, both supra note 75; Ratcliffe v. Walker, supra note 67 ; Smith v. Smith, I92 Mich. 566,159 N. W. 349 (1916). Contra: Hollinghausen v. Ade, supra note 32, where however the decision might better have been put on the ground that the defendant's acts exceeded the privilege.

77 Cole v. Johnson, supra note 75 (aunt).

${ }^{78}$ Weyer v. Vollbrecht, 208 Iowa 914, 224 N. W. 568 (1929).

m Trumbull v. Trumbull, 71 Neb. 186, 98 N. W. 683 (I904).

of Brison v. McKellop, 4I Okla. 374, I38 Pac. I54 (I9I4); Townsend v. Holderby, I97 N. C. 550, I49 S. E. 855 (I929). Cf. Barbee v. Armstead, 32 N. C. 530 (1849).

si Powell v. Benthall, supra note 76 . In Luick v. Arends, 21 N. D. 614, I32 N. W. 353 (IgII), it is asserted that a brother-in-law is presumptively unjustified in interfering; but the court admits that circumstances will often justify him.

${ }_{8}$ Turner v. Estes, 3 Mass. 317 (I807). 
alienated wife was entitled to the privilege, ${ }^{83}$ though the soundness of this ruling may well be doubted, as a former fiancé is hardly justified in interfering with the marital rights of his successful rival. On the other hand it would seem that an old family servant not in any way related to the alienated spouse, but who had assisted in bringing him up, should have the same privilege. $^{84}$

The privilege, when it can be invoked by the defendant, operates so as to enable him successfully to defend an action which would otherwise in all probability be decided unfavorably to him. Sometimes the privilege merely puts a greater burden of proof upon the plaintiff than otherwise would be the case; ${ }^{85}$ the presumption then operates primarily as a matter of evidence. More often it results in the defendant's being excused notwithstanding the fact that he is definitely proved to have done acts which aside from his relations to the alienated spouse would certainly make him legally liable for such alienation. ${ }^{86}$ The matter is well summarized by the Supreme Judicial Court of Maine, as follows: ${ }^{87}$

". . . But it is universally conceded that a parent stands on different ground. Though the wife has gone out from the parental home, and has joined her husband 'for better, for worse,' and though she owes to him marital allegiance, and he possesses the first and the superior right to her affection and comfort and society, it is nevertheless true that the parental relation is not ended, nor has parental affection and duty ended. . . . A parent may not with hostile, wicked or malicious intent break up the relations between his daughter and her husband. He may not do this simply because he is displeased with the marriage, or because it was against his will, or because he wishes the marriage relation to continue no longer. But a parent may advise his daughter, in good faith, and for her good, to leave her husband, if he, on reasonable grounds, believes that the further continuance of the marriage relation tends to injure her health, or to destroy her peace of mind, so that she would be justified in leaving him. A parent may, in such case, persuade his daughter. He may use proper and reasonable arguments, drawn, it may be, from his greater knowledge and wider experience. Whether the motive was proper or improper is always to be considered. Whether the persuasion or the argument is proper and reasonable, under

${ }^{2}$ Cole v. Johnson, supra note 75 .

ss See White v. White, supra note 43.

$\approx$ Gregg v. Gregg, supra note 5; Beem v. Beem, supra note 69; Cornelius v. Cornelius, 233 Mo. I, I35 S. W. 65 (I9II) ; Hostetter v. Green, 150 Ky. 55I, I50 S. W. 652 (I912); Cooper v. Cooper, I02 Kan. 378, I7 I Pac. 5 (IgI8) ; Schneider v. Tapfer, 92 Ore. 520, I80 Pac. I07 (IgIg); Birchfield v. Birchfield, 29 N. M. I9, 2I7 Pac. 6r6 (I923) ; McLery v. McLery, I86 Wis. I37, 202 N. W. I56 (I925); Miller v. Levine, I30 Me. 153, I54 Atl. I74 (193I); Noles v. Noles, 223 Ala. 554, I37 So. 19 (193I). A statute permitting a wife to bring an alienation suit does not, of course, remove this presumption in favor of parents. Wilson v. Wilson, supra note 4I. It has been pointed out that to hold parents because of their greater opportunities to alienate the affections of their child would put them in a worse situation than a stranger. Spiry v. Spiry, 47 S. D. 500 , I99 N. W. 778 (I924).

${ }^{80}$ See the full discussion in Multer v. Knibbs, I93 Mass. 556,79 N. E. 762 (1907).

${ }^{57}$ Oakman v. Belden, 94 Me. 280, 282, 47 At1. 553 (I900). 
the conditions presented to the parent's mind, is also always to be considered. It may turn out that the parent acted upon mistaken premises, or upon false information, or his advice and his interference may have been unfortunate; still, we repeat, if he acts in good faith, for the daughter's good, upon reasonable grounds of belief, he is not liable to the husband." ss

This presumption in favor of the parents and other relatives is undoubtedly the most important defense which can be raised in an alienation suit. While, as indicated in the above quotation, it is more frequently applied when the alienated spouse is the wife, yet it is also applicable where the wife brings the suit for her husband's alienation. ${ }^{89}$

It is not, however, a complete defense. An examination of the authorities would probably show that more suits for alienation of affections are brought against parents and other very close relatives of the alienated spouse than against any other class of persons. As has been shown, the very relationship of parent and child justifies considerable interference even if the child is married; but unlike the Roman law, our law does not give the parents an absolute right to interfere. ${ }^{90}$ They or other close relatives may interfere almost to the limit so long as such interference is the result only of consideration of the benefit of their child or other relative; but when it is dictated primarily by malice toward the spouse of that child the privilege ceases and the liability is the same as that of a stranger. ${ }^{91}$ There are almost innumerable cases where parents and other close relatives have been held liable in this sort of suit, the court finding that there was sufficient evidence to indicate malice toward the plaintiff on the part of the defendants so as to justify a verdict in his favor, notwithstanding the favorable presumption to which the defendants were entitled. ${ }^{22}$ The parents of one of the spouses are not required to be pleasant to the other spouse ${ }^{93}$ and a fortiori are not

${ }^{8}$ Among other important cases reaching the same result, and on similar reasoning, are Kleist v. Breitung, 232 Fed. 555 (C. C. A. 2d, I916); Hutcheson v. Peck, 5 Johns. Ig6 (N. Y. I809) ; Bennett v. Smith, 2I Barb. 439 (N. Y. I856); Rabe v. Hanna, 5 Ohio 530 (I832); Noll v. Carlin, I01 Ore. 203, I99 Pac. 596 (I92I) ; Beisel v. Gerlach, 22I Pa. 232, 70 Atl. 721 (1908); Payne v. Williams, 4 Baxt. 583, (Tenn. I874); Boland v. Stanley, supra note I; Oyler v. Fenner, sipra note 50. Parents are not subjected to liability for unjustly though honestly blaming their son's wife for his marital difficulties, when the son himself was really to blame. Fronk v. Fronk, I59 Mo. App. 543, I4I S. W. 692 (I9II).

${ }^{\circ}$ Reed v. Reed, 6 Ind. App. 317, 33 N. E. 638 (IS92); Melcher v. Melcher, Ioz Neb. 790,169 N. W. 720 (1918). The defense need not be pleaded. Stephenson v. Stephenson, 2 I3 Ala. 545, I05 So. 867 (I925).

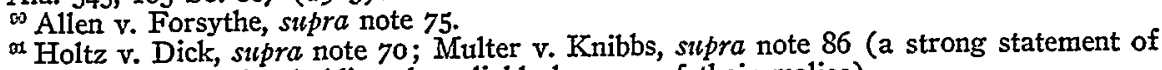
the parents' privilege, but holding them liable because of their malice).

See cases cited supra note 9I. See also Gross v. Gross, supra note 36; Ratcliffe v. Walker, supra note 67; Francis v. Outlaw, 127 Md. 315, 96 Atl. 5I7 (1916) ; Clark v. Clark, I87 Ind. 25, II8 N. E. I23 (I9I7); Jones v. Jones, 96 Wash. I72, I64 Pac. 757 (I9I7); Hope v. Twarling, IrI Neb. 793, I98 N. W. I6r (I924); Porter v. Porter, 258 S. W. 76 (Mo. App. 1924); Nelson v. Nelson, supra note 68; Woodhouse v. Woodhouse, 99 Vt. 9I, 130 Atl. 758 (1925).

${ }^{2}$ Smith v. Smith, supra note 76. 
required to permit that other spouse to live with them or to support him; ${ }^{94}$ but if the parent is actuated by malice toward his daughter's husband or his son's wife his alienation of the affections of that child subjects him to liability. The situation is thus somewhat analogous to the qualified privilege in libel and slander ${ }^{95}$ but the analogy is not perfect, at least with respect to damages. ${ }^{96}$

Here, as in many other branches of the law, the problem of the proper definition of malice is a somewhat troublesome one. It is well known that the courts have so treated this word as to make it mean practically anythingor rather, nothing. In this case it has retained large traces of its original meaning of spitefulness. It has been said that spite is not necessary, but that malice involves an intentional wrong; ${ }^{97}$ but under the circumstances of this situation it would be hard to find an intentional wrong which was not motivated at least in part by spitefulness, particularly as ill-treatment or rudeness to the spouse of the child is regarded as relevant evidence of the necessary malice. ${ }^{98}$ Malice in this connection has also been defined as "a wrongful act done intentionally without just cause or excuse." 99 Disregarding the somewhat hypercritical suggestion which might be made that this is the definition of a malicious act rather than of abstract malice, this seems to amount to much the same as spitefulness; and this may also be said of another court's definition of malice as "wrongful and unjustifiable conduct", ${ }^{100}$ since in applying this latter definition the parent would be justified and his conduct not wrongful unless it is actuated by ill-feeling to the spouse of his child. ${ }^{101}$ On the whole, therefore, the plaintiff who sues the parent or other close relative for alienation of affections of his spouse will have little chance of success unless he can show reasonable evidence that the defendant was actuated at least in some measure by ill-will toward the plaintiff himself; though it must be conceded that many cases have arisen where such malice was found to have been proved, and probably rightly so. ${ }^{102}$

The privilege of parents and other near relatives is by no means confined to a mere presumption in their favor. It is settled that they may do many things which are unquestionably beyond the powers of strangers. For

as Beisel v. Gerlach, supra note 88.

* See I Bishop, Markiage, Divorce and Separation (I891) § I364.

${ }^{30}$ Greuneich v. Greuneich, 23 N. D. 368, I37 N. W. 4I5 (I9I2). See also Cornelius v. Cornelius, supra note 85 .

${ }^{87}$ Westlake v. Westlake, sitpra note 36 ; Wallace v. Wallace, 85 Mont. 492 , 279 Pac. 374 (1929).

${ }_{8}$ Heisler v. Heisler, supra note $7 I$; Lanigan v. Lanigan, supra note 25.

"Nelson v. Nelson, supra note 68, at 375. See also McAllister v. McAllister, supra note 68 .

${ }^{100}$ Shalit v. Shalit, I26 Me. 29I, 138 Atl. 7o (1927).

${ }^{101}$ Ramsey v. Ramsey, 34 Del. 576, I56 Atl. 354 (1931). Cf. Allard v. LaPlain, stupra note 7. In Sargent v. Robertson, supra, note 62 , it was held that a parent's malice must be shown-but need not necessarily be "express malice".

${ }^{102}$ See cases cited supra notes $9 \mathrm{I}$ and 92. 
example, parents may receive a married child into their home and may keep him as long as he is willing to stay. ${ }^{103}$ They must not keep him there against his will, ${ }^{104}$ unless this becomes necessary because of the child's mental incapacity to make this decision for himself. ${ }^{10 \pi}$ They may, however, advise their child against returning to his or her spouse. ${ }^{100}$ They may go further, and actually advise their child or other relative to leave his spouse and to come to live with them. ${ }^{107}$ The only restriction on this is that the advice be bona fide and not the result of ill feeling toward the other spouse. If it is bona fide, the fact that the court may feel that it was ill advised or that it was the result of misrepresentation made to the defendant by the alienated spouse will not subject the defendant to any liability. ${ }^{108}$ Nor is the fact that the parent or other close relative has acted somewhat inconsiderately in his dealings with the plaintiff sufficient of itself to subject him to liability. ${ }^{109}$ It has been held, however, that parents may not threaten to disinherit a son unless he leave his wife although they would have been justified in doing the thing which they threaten to do. ${ }^{110}$

In view of the well-settled presumption in favor of parents, which is a matter of substantive law, it would appear that it is unnecessary for a defendant parent to plead such presumption, ${ }^{111}$ though the rule may not be the same with respect to other relatives relying upon the same presumption. ${ }^{112}$ It has even been held that a complaint for alienation of affections is defective if neither malice nor the relation of the plaintiff to the defendant is alleged, since the defendant may have been a parent or other close relative of that spouse and therefore entitled to the presumption in his favor. ${ }^{113}$ It may be questioned if this case does not go too far. On the other hand it has been held that a parent is not entitled to the presumption in his favor unless he claims it in his pleadings: ${ }^{114}$ a decision which seems to go too far in the other direction. It indicates the desirability for a defendant who wishes to take advantage of this defense of making his claim clear in his pleadings.

${ }^{100}$ Burnett v. Burkhead, 21 Ark. 77 (I860) ; Powell v. Benthall, supra note 76; McGregor v. McGregor, II5 S. W. 802 (Ky. I909); Noll v. Carlin, supra note 88. They may also take their child away from his spouse if the child requests it. Ray v. Parsons, I83 Ind. 344, I09 N. E. 202 (IgI5).

Ior Holtz v. Dick, supra note 70; Beisel v. Gerlach, supra note 88; Lyen v. Lyen, 98 Wash. 498, 167 Pac. III3 (I9I7); Lane v. Dunning, supra note I.

Iar Horowitz v. Sacks, 89 Cal. App. 336, 265 Pac. 28I (I928).

${ }^{100}$ Glass v. Bennett, sutpra note 75 ; Pooley v. Dutton, supra note 69.

${ }^{207}$ Rice v. Rice, I04 Mich. 37I, 62 N. W. 833 (I895).

${ }^{103}$ Ray v. Parsons, supra note I03; Bourne v. Bourne, supra note 48.

${ }^{100}$ McGregor v. McGregor, supra note I03; Bourne v. Bourne, supra note 48 .

${ }^{20}$ Woodhouse v. Woodhouse, supra note 92.

I11 Reed v. Reed, supra note 89; Baird v. Carle, supra note 75.

${ }^{112}$ See Ruhs v. Ruhs, I05 Neb. 663, I8I N. W. 547 (xg2I).

${ }^{113}$ Ellsworth v. Shimer, 7I Misc. 576, I28 N. Y. Supp. 883 (I9II).

"woom v. Vinson, I96 Ky. 449, 244 S. W. 894 (I922). 
Assuming that the privilege of a parent or other near relative is properly before the court, it is still not evidence in his behalf: ${ }^{11 \sigma}$ it merely increases the burden upon the plaintiff by requiring him to prove malice or other improper motive upon the part of the defendant, instead of merely proving the latter's complicity in the alienation, which would be sufficient in the case of a stranger. However, a charge to the jury which ignores the favorable presumption accorded to a relative where the defendant is entitled to the same, is reversible error. ${ }^{116}$

One peculiar application of the favorable presumption accorded to a parent in this sort of case is discussed in the case of Wolf $v$. Wolf. ${ }^{117}$ Here the alienated spouse (a son) was under the statutory age for marriage. Under the law of the state, his parents had a right to bring proceedings for the annulment of the marriage. This they did, but only after they had persuaded the son to leave his wife. The latter sued her former parents-in-law for the alienation of his affections. The lower court held that she was entitled to recover; that the marriage though voidable was valid until actually annulled and that until the decree of annulment the parents had no right to alienate the son's affections from his wife. This would appear to be the correct view, but the decision was reversed, ${ }^{118}$ because the upper court felt that the rights of the defendants to annul the marriage included a right to alienate their son's affections prior to the annulment. It is submitted that this is giving the parents an unnecessary and therefore improper privilege. ${ }^{119}$ At any rate, it seems clear that the sub-statutory age for marriage of their child would give the parents no right to alienate his affections in jurisdictions where they have no right to annul his marriage.

The presumption in favor of a parent or other close relative necessarily involves a lack of such presumption in favor of any one else; and in fact it is generally held that the presumption is strongly against a stranger. ${ }^{120}$ No doubt a stranger is justified in sheltering a wife who is driven away from home by the cruelty of her husband, ${ }^{121}$ but this is about as far as he can go. The matter is well stated by the Supreme Court of Missouri in Modisett $v$. McPike, ${ }^{122}$ as follows :

". . . The wife may have a just cause for separation or divorce, but she may elect to abide by her situation, and remain with her husband nevertheless. If she chooses to do so, no stranger has the right to inter-

${ }^{110}$ Woodhouse v. Woodhouse, supra note 92 , the court stating that the presumption is merely "locative".

${ }^{110}$ Greuneich v. Greuneich, supra note 96.

${ }_{112}$ I II Misc. 39I, I8I N. Y. Supp. 368 (I920).

I1s 194 App. Div. 33, 185 N. X. Supp. 37 (1920).

110 See (Ig2I) 30 Y ALE L. J. 527.

100 Smith v. Mitchell, 64 Cal. App. 463, 221 Pac. 964 (I923) ; Rose v. Dean, I92 N. C. 556, I35 S. E. 348 (I926); Alexander v. Johnson, I82 Ark. 270, 31 S. W. (2d) 304 (1930).

121 Berthon v. Cartwright, 2 Esp. 480 (Eng. I796). But a stranger may probably assist a wife to leave a cruel husband, if she requests it. See Ray v. Parsons, supra note Io3.

74 Mo. 636,646 (I88I). 
meddle with the domestic and marital relations of husband and wife, and if he voluntarily does so he is amenable for the consequences. If, on the contrary, the wife having just cause for the separation or for obtaining a divorce from her husband, voluntarily seeks the advice, shelter and protection of a relative, or even a stranger, then a different rule obtains. In such a case the wife has the unquestioned right to seek and accept the advice and protection of a relative or stranger from the intolerable abuse and wrongs of her husband. And in such case, also, such relative or stranger so affording such protection or advice to the wife, is not answerable to the husband for such conduct, if he acts in good faith and from motives of kindness and humanity. No one unasked, especially a stranger, has the right to volunteer his advice or protection, and if he does so he is amenable." ${ }^{123}$

The stranger may possibly justify his interference by showing that it is fairly incidental to some business or social relationship with the alienated spouse, as for example by the fact that it is incident to his employment of such spouse $;^{124}$ but this is a defense the proving of which is an affirmative burden on the defendant - it need not be negatived by the plaintiff. ${ }^{125}$ There are some authorities who talk about the necessity of the proof of malice on the defendant's part even when he is a stranger ; ${ }^{126}$ this is only another proof of the practical worthlessness of the word "malice" in this connection, since the burden is met by proof that the defendant acted intentionally and without apparent justification. So much must, of course, be proved by the plaintiff in any case. The better rule is that malice on the part of a stranger need neither be alleged nor proved, and that his motive is immaterial. ${ }^{12 \pi}$

Another entirely separate defense, which may be available to any defendant in an alienation suit, is that the spouses had no affection for each other prior to the defendant's interference. Since the gist of the action is loss of consortium rather than mere loss of affections, this would seem not to be necessarily a bar; yet it must be admitted that rights of consortium with a spouse who has no affection whatever are obviously worth very little. It may therefore be urged reasonably that to allow the prosecution of an alienation action in such circumstances is undesirable $;^{128}$ and there are several authorities so holding. ${ }^{129}$ Even in these jurisdictions, however, punitive damages have been granted in aggravated cases, although no substantial damages appeared because of the almost total lack of affection between the spouses. ${ }^{130}$

${ }^{203}$ See also Hartpence v. Rogers, I43 Mo. 623, 45 S. W. 650 (I898).

ins Jennings v. Cooper, stipra note $5 \mathrm{I}$.

2 I I bid.

${ }^{10}$ Rose v. Dean; Alexander v. Johnson, both supra note I20.

${ }^{1 \pi}$ Grilnberger v. Brotherton, 22 P. (2d) 983 (Wash. 1933).

123 See HARPER, TORTS (I933) \$256.

20 Servis v. Servis, I72 N. Y. 438, 65 N. E. 270 (Ig02); Madison v. Neuburger, supra note 59; McGregor v. McGregor, silpra note 103.

iw Buteau v. Naegeli, I24 Misc. 470, 208 N. Y. Supp. 504 (1925), rev'd, 216 App. Div. 833,215 N. Y. Supp. 823 (Ig26). 
The weight of authority seems to be to the contrary-that is to say, that total lack of affection between the spouses is not a bar to liability of the defendant for subsequent interference. ${ }^{131}$ The theory of these courts is that the plaintiff should not be deprived of the chance, whatever it may be worth, of subsequently effecting a reconciliation with his spouse.

It is easy to exaggerate the significance of this division of opinion. All courts would probably agree that a substantial lack of affection between the spouses, even though not wholly complete, may be shown in mitigation of damages. ${ }^{132}$ Furthermore there is a well settled rule that the spouses will always be presumed to have had some affection prior to the defendant's interference. ${ }^{133}$ The result is that even where a complete lack of affection is a bar to the action, the defendant has the burden of showing this; and such a burden is apt to be heavy.

Besides all this it is entirely clear that the defendant is liable in practically all jurisdictions if he prevents reconciliation between the spouses even though the relationships between them are somewhat strained. Even Massachusetts ${ }^{134}$ admits this, the court saying:

". . . Any unhappy relations existing between the plaintiff and wife, not caused by the conduct of the defendant, may affect the question of damages, and were properly submitted to the jury; but they are in no sense a justification or palliation of the defendant's conduct. They are not allowed to affect the damages because the acts of the defendant are less reprehensible, but because the condition of the husband is such, that the injury, which such acts occasion, is less than otherwise it might have been." 135

The rule is not affected by the fact that the relationships are extremely strained and that the quarrels between the spouses are somewhat violent, so long as there is even a vestige of affection between them; $;^{136}$ and as already shown, this last is presumed. Even though the spouses have actually separated before the defendant interfered he may still be liable. This is obviously true if the spouses both desire to become reconciled; ${ }^{137}$ it likewise applies

${ }^{15 \pi}$ Dey v. Dey, 94 N. J. L. 342, Iro Atl. 703 (I920) ; Halpern v. Mendel, Iro N. J. L. 552, I66 Atl. I72 (I933) ; Olsen v. Erickson, 152 Wash. 633,278 Pac. 692 (1929) ; Rash v. Pratt, 3I Del. I8, III Atl. 225 (I920) ; Sargent v. Robertson, supra note 62.

${ }^{139}$ Payne v. Williams, supra note 88; Moelleur v. Moelleur, supra note 60; Beem v. Beem, supra note 69; Okrent v. Raffa, supra note 73; Alex v. Strickland, supra note 18; Amellin v. Leone, II4 Conn. 478, I59 Atl. 293 (I932).

${ }^{133}$ Beach v. Brown, supra note 46; Gregg v. Gregg, supra note 5; Annarina v. Boland, supra note 8; Overton v. Overton, I2I Okla. I, 246 Pac. I095 (I926); Weyer v. Vollbrecht, supra note 78 ; Buckley v. Francis, 78 Utah 606, 6 P. (2d) I88 (I93I).

${ }^{134}$ Hadley v. Heywood, supra note $6 \mathrm{r}$.

135 Id. at 239 .

${ }^{153}$ Johnson v. Allen, Ioo N. C. I3I, 5 S. E. 666 (I888) ; Philpott v. Kirkpatrick, I7I Mich. 495, I37 N. W. 232 (1912) ; Scott v. Bontekoe, 252 Mich. I85, 233 N. W. 2I5 (I930) ; Joseph v. Naylor, supra note 15 ; Bradbury v. Brooks, supra note 13 . The same is true if the parties were already so estranged that they later obtained a divorce. Munson v. Solace, 66 Mont. 70, 212 Pac. 1103 (1923).

${ }^{137}$ Hollinghausen v. Ade, supra note 32. 
even though no such desire appears on the part of the alienated spouse, since there is always a chance of reconciliation. ${ }^{138}$ The separation does not prove that there may not be some latent affection still existing between the spouses, ${ }^{139}$ though it has been held that the defendant is not liable if he can prove affirmatively that no reconciliation was reasonably possible. ${ }^{140}$

With all these difficulties in the way of a defendant seeking to make use of this defense it seems clear that the lack of affection between the spouses, even if regarded as a bar to the action, is not ordinarily a particularly valuable defense except as a matter of mitigation of damages; this use of it is possible in all jurisdictions.

Another defense which is frequently set up is that the spouses have been divorced or otherwise permanently separated. Here too the defense almost invariably fails to present an absolute bar to the action, ${ }^{141}$ though it will often be considered as a basis for mitigation of damages. That the divorce was obtained by the alienated spouse through the fault of the plaintiff in the alienation action does not necessarily preclude him from relief, ${ }^{142}$ since as already pointed out, the alienated spouse, though having grounds for divorce, might well not have obtained it had it not been for the defendant's interference. ${ }^{143}$ The fact that the alienated spouse after the divorce marries the defendant obviously will not improve the position of the latter in the alienation action. ${ }^{144}$ Even more clearly a divorce obtained by the plaintiff because of the fault of the alienated spouse does not bar the action, since that fault of the alienated spouse is presumably at least partly due to the defendant's unjustified interference. ${ }^{145}$ Nor does the fact that the plaintiff in the alienation suit (the wife) secured alimony from her husband bar the suit: ${ }^{146}$ the alimony does not compensate her for the defendant's wrong, since it does not restore her right of consortium with her husband. It need scarcely be added that if the alienated spouse has failed in an attempt to secure a divorce from the plaintiff this cannot help the defendant ${ }^{147}$ except possibly as evidence of previous lack of affection between the spouses.

IFs Porter v. Porter, supra note 92; Amellin v. Leone, supra note I32. See also Davenport v. Holden, 95 N. J. L. I97, II2 Atl. 4I8 (I920).

${ }^{109}$ Morris v. Warwick, 42 Wash. 480,85 Pac. 42 (Ig06).

${ }^{200}$ Rush v. Buckles, 93 W. Va. 493 , II7 S. E. I30 (Ig23).

111 See Note (I922) 20 A. L. R. 936. See also Sickler v. Mannix, 68 Neb. 2I, 93 N. W. IoI8 (I903); Luick v. Arends, supra note 8I.

${ }_{112}$ Dunbier v. Mengedoht, II9 Neb. 706, 230 N. W. 669 (r930). See also Knickerbocker v. Worthing, I38 Mich. 224, I0I N. W. 540 (1904); Eklund v. Hackett, supra note 50; Lundstrom v. Nelson, supra note 62.

${ }_{113}$ Philpott v. Kirkpatrick, stupra note 136; Pollard v. Ward, 289 Mo. 275, 233 S. W. 14 (192I).

${ }^{\text {us }}$ Keen v. Keen, supra note 36 .

${ }^{2 w}$ Luick v. Arends, supra note 8r.

${ }^{210}$ Hope v. Twarling, supra note 92 ; Case v. Case, 212 Iowa 1213, 238 N. W. 85 (I93I).

${ }^{137}$ Cole v. Johnson, supra note 75. 
Since divorce is no bar to the alienation action, a like rule applies to a judicial separation. ${ }^{148}$ The same is true with respect to an actual separation without judicial proceedings either when the alienated spouse deserts the plaintiff ${ }^{149}$ or when the plaintiff leaves his spouse as a result of the fault of the latter. ${ }^{150}$ A contract between the spouses by which each gives up all rights against the other would seem to be no bar to the alienation suit since the plaintiff does not thereby give up his rights, if any, against the defendant, who is not a party to the agreement. ${ }^{151}$ By the same token a separation agreement between the spouses is no bar to an alienation suit, ${ }^{152}$ as the defendant is not a party to the agreement; furthermore the defendant is presumably responsible for the estrangement between the spouses which led to the separation agreement.

Nor is the suit necessarily barred by the fact that the spouses have not separated and have continued to cohabit. ${ }^{153}$ This may make it difficult to show a loss of consortium, and in any event is likely to mitigate damages; but if a substantial loss of consortium, even though only partial, ${ }^{154}$ can be proved as a result of the defendant's unjustified interference, the continued cohabitation of the plaintiff with the alienated spouse is not a bar to the action. Even more clearly, the resumption of cohabitation by the spouses, if the previous separation was the defendant's fault, does not preclude an alienation action. ${ }^{155}$ It may be said that under these circumstances the plaintiff has reclaimed his rights of consortium but is still entitled to a remedy against the defendant for the temporary deprivation thereof. ${ }^{156}$

There is one jurisdiction which takes the opposite view with respect to divorce. This is Iowa, which holds that a divorce of the spouses precludes an action for alienation of affections. ${ }^{157}$ The holding seems hardly justifiable, for the reasons already set forth, but the opinion is predicated upon a statute providing that "when a divorce is decreed the guilty party forfeits all rights acquired by the marriage." It is believed that the statute has been given too broad a construction by the court $;^{158}$ but in any case its very existence effectively prevents the Iowa doctrine from being regarded as authority in any other jurisdiction.

${ }^{14 s}$ Wilson v. Coulter, 29 App. Div. 85, 5I N. Y. Supp. 804 (1898).

1* Hollinghausen v. Ade, supra note 32 .

${ }^{250}$ Callis v. Merrieweather, $98 \mathrm{Md}$. 361, 57 Atl. $20 \mathrm{I}$ (r904); Surbeck v. Surbeck, supra note 75 .

100 Jenness v. Simpson, stipra note $\mathbf{I}$.

${ }^{100}$ Annarina v. Boland, supra note 8; Patterson v. Hill, 212 Mich. 635, I80 N. W. 352 (I920). See also Johnson v. Richards, supra note 8.

${ }_{133}$ Heermance v. James, 47 Barb. I20 (N. Y. I866) ; Rinehart v. Bills, 82 Mo. 534 (1884); Foot v. Card, supra note 38 .

${ }^{15 s}$ Murrell v. Culver, supra note 9.

Is Peak v. Rhyno, 200 Iowa 864, 205 N. W. 5I5 (I925); Lavigne v. Lavigne, 80 N. H. 559, II9 At1. 869 (I923).

${ }^{20 s}$ Lavigne v. Lavigne, stupra note $\mathbf{I} 55$.

${ }_{167}$ Duff v. Henderson, I9I Iowa 8I9, I83 N. W. 475 (I92I). The ruling applies only to divorce and not to separation. Peak v. Rhyno, supra note 155 .

${ }^{185}$ See Note (IgII) iI CoL. L. Rev. 367. 
Another plea of justification quite frequently resorted to by defendants in this sort of action is the effect of religious differences between the spouses. Obviously this is quite closely tied up with certain more general defenses, especially the privilege of a parent or other close relative. It is clearly settled that such religious differences do not of themselves justify intentional alienation. $^{159}$ It has even been held that they do not justify a parent in interfering. ${ }^{160}$ It is submitted, however, that such religious differences between the spouses may influence a parent to believe that the continuance of the marital relationship is undesirable: the parent or other close relative should be entitled to show such religious differences on the issue of his good faith. ${ }^{161}$

A final defense which requires consideration is the statute of limitations. This involves two problems: first, under what statute of limitations is the action to be put; and secondly, when does the cause of action become complete? The first problem is primarily one involving construction of the statutes of the particular jurisdiction involved, plus a determination of the nature of the action. No doubt the action is in substance for a personal tort, but it would not follow that the statute of limitations governing such tort (for which the statutory period is usually very short) would apply. ${ }^{\mathbf{1 6 2}}$ It would appear that either statutes governing actions to redress injuries to property rights or else a general catch-all statute should be applied, ${ }^{163}$ in the absence of explicit provision for alienation suits.

The problem of the accrument of the cause of action is still more difficult. Obviously the statutory period does not commence to run until the alienation is complete; and this may become a jury question. ${ }^{164}$ At any rate, acts of the defendant committed prior to the beginning of the statutory period can be shown, since alienation of affections is obviously a somewhat continuous process and may take some time. ${ }^{165}$

If, however, the parties actually separate, the cause of action presumably accrues on the date of separation and the statutory period commences to run at that time. ${ }^{168}$ When the parties separate, it is reasonably clear that the defendant has been successful in his effort to alienate the affections of one of the spouses from the other; but if there is a chance of reconciliation 2fter the separation and the defendant then prevents such reconciliation from materializing, it may well be that there is a new cause of action for alienation, (I924).

${ }^{200}$ Mohn v. Tingley, supra note 29. See Hughes v. Holman, IIo Ore. 415, 223 Pac. 730

${ }_{100}$ Harlow v. Harlow, supra note 75; Wallace v. Wallace, supra note 97.

101 Rice v. Rice, supra note 107.

${ }_{103}$ Gernerd v. Gernerd, I85 Pa. 233, 39 Atl. 884 (1898).

${ }^{1 \approx}$ See Crane v. Ketcham, supra note 7.

${ }^{10}$ Smith v. Lyon, 9 Ohio App. I4I (Igr8).

${ }^{10}$ Davis v. Butler, I98 Ky. 795, 250 S. W. I26 (Ig23) ; Boyd v. Strickland, 237 N. W. 729 (S. D. I93I).

${ }_{263}$ Gooch v. Gooch, II2 Kan. 592, 2 II Pac. 621 (I923) ; Brown v. Brown, sutpra note I; Overton v. Overton, supra note I33. 
and if so, the statute of limitations as to it will of course run only from this subsequent period. ${ }^{167}$ However, if the alienation has clearly been accomplished, the statutory period may begin to run even though the spouses have not yet separated. ${ }^{168}$ And it seems that the plaintiff's laches may preclude him from beginning such a suit though the statute of limitations has not run. ${ }^{169}$

\section{Evidence}

The problem of evidence in actions for the alienation of affections has obvious similarities to that for other sorts of litigation and hence need not be discussed at detail. It may be said in general that the tendency of the courts seems to be toward greater liberality in this sort of action than in most other kinds. ${ }^{170}$ However, no attempt will be made to discuss any topics of evidence except a few, which seem to be somewhat peculiar with respect to this action.

It is clear that circumstantial evidence has large scope here. It is frequently relied on in large part by the plaintiff in establishing his case. ${ }^{171}$ This is necessary because the defendant's activities are often somewhat secret, especially so far as the innocent spouse is concerned. Indirect evidence of alienation is all that is available in many cases. ${ }^{172}$ This liberal treatment of the plaintiff is also extended to the defendant where it is at least as necessary. So evidence, either direct or indirect, which tends reasonably toward possible mitigation of damages is admissible. ${ }^{173}$ This may include evidence contradicting the plaintiff's present testimony which, if it has no other value to the defendant, would at least tend to show that the plaintiff has not in fact been injured as much as he presently claims. ${ }^{174}$ The defendant may also show circumstantial evidence which will substantiate any defense which he makes-as for example that the alienation was the result solely of the volition of the alienated spouse ${ }^{175}$ or of some other cause with which the defendant had nothing to do. ${ }^{176}$

\footnotetext{
${ }^{100}$ See Farneman v. Farneman, 46 Ind. App. 453, 90 N. E. 775 (I9I0).

${ }^{163}$ Pray v. Millett, I22 Me. 40, II 8 Atl. 72 I (I922). See also French v. Deane, I9 Colo. 504, 36 Pac. 609 (I894).

${ }^{2}{ }^{2}$ Churchill v. Lewis, I7 Abb. N. C. 226 (N. Y. I886).

${ }^{170}$ See 13 R. C. L. 1475 .

274 Wilson v. Coulter, supra note I48; Hardwick v. Hardwick, r30 Iowa 230, ro6 N. W. 639 (1906); Fuller v. Robinson, 230 Mo. 22, 130 S. W. 343 (1910); Beit v. Belt, 288 S. W. IOO (Mo. App. I926).

${ }_{\text {ג72 }}$ Doom v. Vinson, supra note II4.

$x \rightarrow$ Hardwick v. Hardwick, supra note I7I; Annarina v. Boland, supra note 8; Murrell v. Culver, supra note 9; Helminiak v. Przekurat, I84 Wis. 4I7, I98 N. W. 746 (1924); Shalit v. Shalit, supra note Ioo.

${ }^{274}$ Bassett v. Bassett, 20 I11. App. 543 (1886); Johnson v. Richards, supra note 8.

${ }^{2 \pi}$ Harper v. Harper, 252 Fed. 39 (C. C. A. 4th, 1918); Bassett v. Bassett, supra note I74.

${ }^{770}$ Rudd v. Rounds, 64 Vt. 432, 25 At1. 438 (I892). See also Strock v. Russell, I48 App. Div. 483 , I32 N. Y. Supp. 968 (I III).
} 
The most frequent employment of circumstantial evidence in alienation cases is in connection with the issue of malice when the defendant is entitled to the privilege of a near relative. It is clear that malice, here in the proper sense of spitefulness, can rarely be proved except by circumstantial evidence; accordingly such evidence is admissible. ${ }^{177}$ Evidence may be pertinent as tending to show the malice of the defendant even though it consists of his refusal to do something which he was not legally bound to do; ${ }^{178}$ for such refusal, even though legally justified, may under the circumstances show ill-will toward the plaintiff.

The general problem of the declarations of persons interested in the action is also treated liberally by the courts. In general, declarations of the defendant are admissible against him. ${ }^{179}$ This is particularly true when the declarations were made to the alienated spouse, and presumably influenced the action of the latter even though they cannot be considered a part of the alienation itself. Such declarations are admissible on the issue of the mental state of the defendant. ${ }^{180}$ Thus a letter by the defendant to his son then married to the plaintiff and containing such declarations may be admitted though the letter was intercepted by the plaintiff and never reached her husband. ${ }^{181}$

Declarations of the defendant may in some circumstances be admissible in his favor. The obvious objection to admitting such declarations is that they are self-serving. This objection has not, however, been regarded as conclusive by most courts, ${ }^{182}$ though the self-serving quality would no doubt affect the weight of such evidence.

When we turn to the problem of declarations by the alienated spouse, the problem is even more complicated. That spouse is not a party to the action, although he generally is in fact supporting the defendant. There appears, therefore, to be no problem of privilege involved here, ${ }^{183}$ but there is a problem of pertinency.

Probably the weight of authority permits such declarations to be introduced where they tend to show the feelings of the alienated spouse toward

$2 \pi$ Cornelius v. Cornelius, supra note 85 ; Hayward v. Ham, 29 S. W. (2d) 243 (Mo. App. I930), rev'd on other grounds in 5I S. W. (2d) 79 (I932); Stilwell v. Stilwell, I86 Iowa 177, I72 N. W. I77 (I919); Wallace v. Wallace, sıtpra note 97.

${ }^{178}$ Jackson v. Jackson, 35 S. W. (2d) 830 (Tex. Civ. App. I93I). See also Cornelius v. Cornelius, supra note 85 .

${ }^{270}$ Price v. Price, supra note 36 ; Caplan v. Caplan, supra note 7I. If the declarations are self-serving, they are not so likely to be admitted. Murphy v. Willumsen, 224 I11. App. 425 (1922).

${ }^{183}$ Bourne v. Bourne, supra note 48; Stilwell v. Stilwell, supra note 177.

${ }_{181}$ Mercer v. Parsons, 95 N. J. L. 224, II2 Atl. 254 (I920). Verbal evidence of the contents of a letter from the defendant to his son, the alienated spouse, can be given, if the letter has been destroyed. Bresch v. Wolf, supra note 59.

${ }^{153}$ Scott v. O’Brien, supra note 48 ; Noll v. Carlin, supra note 88.

Is See 3 WigMore, Evidence (2d ed. I923) § r730; 4 Id. \$2239. 
the other spouse, such feelings being of course a pertinent issue in the case. ${ }^{184}$ Such admission of declarations showing the feeling of the declarant toward his spouse does not, however, of itself permit statements showing the reason for such feelings. ${ }^{185}$

Many courts go further and permit such declarations to show the effect on the declarant of the defendant's actions. ${ }^{186}$ Obviously such actions cannot be shown by such testimony; they must be proved independently. ${ }^{187}$ These courts permit evidence of declarations by the alienated spouse to indicate the effect upon him of what the defendant is otherwise proved to have done. Such evidence may also be used to justify the defendant as well as to hold him. ${ }^{188}$

Another theory upon which courts admit the declarations of alienated spouses is under an application of the somewhat dubious res geste theorythat such actions characterize an act of the declarant and are admissible for that purpose. Thus declarations by a wife at or immediately after the time when she separates from her husband that such separation was caused by his cruelty are admissible against him if he brings suit against those who assisted her to escape. ${ }^{189}$ Declarations of this sort may be admissible in favor of either party. ${ }^{190}$ Here too it must be noted that the declarations are not to be regarded as evidence of the facts asserted, but only as evidence of the reasons actuating the alienated spouse in separating. ${ }^{191}$ So far as is possible, the declarations should be segregated into those testifying to the acts of one of the parties to the suit and those describing the effect of those acts upon the declarant. Only the latter type of declaration should be admitted. ${ }^{192}$

Notwithstanding all this, there are several jurisdictions where such declarations of the alienated spouse seem generally to be excluded unless made in the presence of the party against whom the evidence is to be directed. In some cases this ruling is justifiable, since the declarations have little effect except to show the actions of that party, and declarations are not admissible

18s Boland v. Stanley, supra note I; McKenzie v. Lautenschlager, II3 Mich 77I, 7I N. W. 489 (1897) ; Warren v. Graham, 174 Iowa 162, I56 N. W. 323 (I916); Pugsley v. Smyth, supra note 6r ; Coates v. Slusher, I09 Ore. 6I2, 222 Pac. 3II (I924); Trenerry v. Fravel, ro F. (2d) IOII (App. D. C. I926).

${ }^{200}$ Luick v. Arends, supra note 8r. 75.

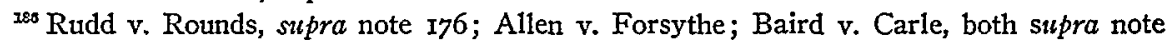

${ }^{157}$ Willey v. Howell, I68 Ky. 466, 182 S. W. 6I9 (IgI6).

${ }^{189} \mathrm{Ibid}$.

${ }^{289}$ Gilchrist v. Bale, 8 Watts 355 (Pa. I839) ; Baker v. Baker, I6 Abb. N. C. 293 (N. Y. 1885). Contra: Bathke v. Krassin, 82 Minn. 226, 84 N. W. 796 (I90I). But such declarations are admissible only if considered strictly a part of the res gesta. Higham v. Vanosdol, I0I Ind. I60 (1884) ; Mumper v. Webster, I37 Ore. 554, 3 P. (2d) 753 (I93I).

${ }^{100}$ Glass v. Bennett, supra note 75.

${ }^{201}$ See the excellent discussion on this point in Murray v. Murray, 30 N. M. 557, 24⿺ Pac. 303 (I925).

${ }^{20}$ Johnson v. Richards, supra note 8. 
for that purpose. ${ }^{193}$ A few authorities lay down flatly the rule that no declarations of the alienated spouse are admissible unless the defendant was present. ${ }^{194}$ Most courts, however, will admit such declarations if they have any pertinency as showing the state of affections of the declarant to his spouse or the effect upon him of the defendant's actions; ${ }^{195}$ and practically all jurisdictions will allow such declarations in so far as they are regarded as within the scope of the res gestce rule. ${ }^{196}$

The most difficult problem with respect to evidence still remains for consideration. This is the problem of evidence of communications between the spouses and, as subordinate thereto, the competency of one spouse to testify against the other in an alienation suit. The problem in both of these situations is one of privilege. The purpose of privilege is to preserve the sanctity of the marital relations-a worthy purpose, which, however, seems not particularly applicable to a situation where the spouses are so estranged that one of them institutes an alienation suit. ${ }^{197}$ Nevertheless, the privilege is still given considerable effect in this sort of case.

Rules enforcing the incapacity of one spouse to testify against the other seem to be applicable in alienation suits even though the spouse seeking to testify is not generally a party to the case. ${ }^{198} \mathrm{He}$ is in fact testifying against his spouse, the plaintiff in the alienation action. A statute permitting one spouse to testify against another in an action between them has been held not to permit such testimony in an alienation action where both spouses are not parties. ${ }^{199}$ Some jurisdictions have statutes permitting such testimony in a pure alienation suit; but the statute is held not to apply when adultery is charged. ${ }^{200}$ Testimony by his spouse in rebuttal of the plaintiff's testimony is regarded as testimony against him and will therefore be excluded under this rule; $;^{201}$ although under some statutes there appears to be a difference as to whether the testifying party is a husband or a wife. ${ }^{202}$

It is submitted that this situation should be clarified by a general statute permitting either spouse to testify generally in alienation actions. Until such a statute is passed, such absurd and often unjust technicalities will clutter our law.

Passing to the more important subject of testimony concerning communications between the spouses, it must first be noted that there is frequently

${ }^{153}$ Moir v. Moir, 18I Iowa 1005, I65 N. W. 22I (I9I7) ; Davis v. Butler, supra note 165; Spiry v. Spiry, supra note 85.

ias Westlake v. Westlake, supra note 36; Manwarren v. Mason, $79 \mathrm{Hu}$
Supp. 915 (1894): Kreager v. Kreager, I92 Ind. 242, 135 N. E. 660 (I922).

${ }_{100}$ See cases sipra notes 186-188.

Ios See cases supra notes I89-I90.

Iro See I3 R. C. L. I480. See also Fratini v. Caslini, 66 Vt. 273, 29 Atl. 252 (I894).

${ }^{100}$ Huot v. Wise, 27 Minn. 68, 6 N. W. 425 (I880); Lyen v. Lyen, stupra note I04.

$\approx 0$ Knickerbocker v. Worthing, supra note I42.

sor Rice v. Rice, supra note Io\%.

${ }_{\infty}$ See McGinnis v. McGlothlan, I92 Mo. App. I4I, I80 S. W. 405 (1915). 
the same problem of proving the communications. If the spouse of the plaintiff is to testify to them, he may be excluded under the rule that he cannot testify against his spouse. ${ }^{203}$ However, there are frequently means of avoiding the rule. It may be that the testimony will be favorable to his spouse; the testimony respecting the communications may be given by the plaintiff himself; or there is the possibility that the communications are in some permanent form, like letters which obviate the necessity of any substantial verbal testimony. In all this we still have the rather artificial but distinctly knotty problem of the violation of the marital relations.

Perhaps because letters are not subject to the frailties of human recollection and perhaps also because it is thought that the marital relation is less affected by such evidence, the general tendency is to admit pertinent letters between the spouses. ${ }^{204}$ Even though the letters were written after the separation, they may still be admitted, though probably carrying less weight. ${ }^{205}$ Here again only those parts of the letters which are pertinent should be read to the jury; so far as is possible mere allegations of the defendant's alleged wrongdoing should be omitted. ${ }^{206}$ Letters containing a mere narrative of the defendant's acts ${ }^{207}$ or objectionable for other reasons ${ }^{208}$ should, of course, be excluded.

The subject of verbal communications between the spouses is complicated not only by the predisposition of the courts to frown upon such testimony but also, in some cases, by statutes. Some statutes appear to exclude all evidence of such declarations for any purpose. ${ }^{209}$ The Kentucky court has gone so far as to hold that the husband's indifferent treatment of his wife cannot be testified to by her in an alienation suit which she brought, on the ground that such indifferent treatment is itself a communication to the wife falling within the prohibition of the statute. ${ }^{210}$ Probably no other court would carry the statutory rule to this absurd extent, but most of them construe the statutes with at least considerable-and it seems, undesirable-

${ }^{\infty}$ See Knickerbocker v. Worthing, supra note $\mathbf{1 4 2 .}$

sat Beach v. Brown, snipra note 46 ; Cottle v. Johnson, I79 N. C. 426 , 102 S. E. 769 (1920); Disch v. Closset, supra note 20; Rockwell v. Rockwell, supra note 66 . A letter written by the alienated spouse to the defendant is not to be regarded as a communication between the spouses, even though written in the presence of the plaintiff. Weston v. Weston, 86 App. Div. $159,83 \mathrm{~N}$. Y. Supp. 528 (I903). The letter is, however, admissible as a declaration of the alienated spouse. Ibid.

Freund v. Freund, 8 N. J. Misc. 675, 15I At1. 375 (1930).

${ }^{200}$ Ash v. Prunier, I05 Fed. 722 (C. C. A. 2d, I90I).

${ }^{\infty}$ Bevers v. Bradstreet, supra note 58.

${ }^{20}$ Rasanen v. Vünamaki, I03 Vt. 323, I54 Atl. 69I (r93I).

${ }^{20}$ Watkins v. Lord, supra note II; Kreager v. Kreager, supra note I94; Gjesdahl v. Harmon, x75 Minn. 4I4, 221 N. W. 639 (I928).

${ }^{210}$ Allcock v. Allcock, I74 Ky. 665, I92 S. W. 853 (I9I7). This decision seems contrary to the decision of the same court the previous year in Merritt v. Cravens, supra note 9. Testimony of acts is not testimony as to declarations. Brister v. Dunaway, I49 Miss. 5, II5 So. 36 (1928). 
rigidity. ${ }^{211}$ The Utah court has admitted that its statute may be "barbaric", but says it must be literally followed anyway. ${ }^{212}$

One or two courts have taken what seems to be a more sensible view : they have held that the statute is directed only at privileged communications -which would seem to mean communications the disclosure of which would have a disturbing effect upon the stability of the marriage. ${ }^{213}$ Non-privileged communications are said by the Nebraska court to be possibly within the letter but certainly not within the spirit of the statute. ${ }^{214}$ This is a highly desirable point of view, though it must be confessed that it makes the statutes of comparatively little effect.

In the absence of a statute pertaining to communications between spouses, many courts admit such evidence to show the feelings of the spouses toward each other. ${ }^{215}$ This seems quite unobjectionable, since such communications would not necessarily make any reference to the defendant or be influenced by him..$^{216}$ It has been suggested that such declarations made by the alienated wife to her husband who brings the suit are not within the hearsay rule at all.217 This is probably incorrect, but it seems that such declarations are within the exception to the hearsay rule relating to feelings and intentions.

Many courts will go further and permit evidence of communications between spouses, not merely as showing the relations between the spouses, but also as showing the effect on the alienated spouse of the defendant's actions ${ }^{218}$ - which must, of course, be otherwise proved. ${ }^{219}$ Such testimony may favor the defendant as showing that the alienation resulted from something else other than his actions. ${ }^{220}$ Such communications should be restricted to the purposes already stated and, so far as is practical, mere statements concerning the defendant's alleged actions should be excluded. ${ }^{221}$ All such testimony must be conceded to be somewhat dangerous as tending to be prejudicial. It should be restricted carefully. ${ }^{222}$

Since the parts of such communications between the spouses relating solely to alleged acts of the defendant should be excluded so far as is prac-

211 Kreager v. Kreager, supra note I94.

Iis Smith v. Sheffield, 58 Utah 77, 197 Pac. 605 (1921). (1924).

as Patterson v. Hill, supra note 152; Stocker v. Stocker, II2 Neb. 565, I99 N. W. 849

is Stocker v. Stocker, supra note 213.

215 Hillers v. Taylor, II6 Md. 165, 8r Atl. 286 (I9II) ; compare same case on previous appeal in I08 Md. 148, 69 Atl. 7I5 (I908); Wallace v. Wallace, supra note 97.

${ }^{a}$ Fuller v. Robinson, stipra note I7I.

${ }_{m 2}$ Clendennen v. Bainbridge, 45 S. D. 4 Io, 187 N. W. 727 (1922).

mose v. Mitchell, 2I R. I. 270, 43 Atl. 67 (I899); Hardwick v. Hardwick, supra note I7I; Hayward v. Ham, supra note I77; Daywitt v. Daywitt, 63 Ind. App. 444, II4 N. E. 694 (Igr7) ; Nelson v. Nelson, stipra note 68; Fox v. Fuchs, 24I Ill. App. 242 (1926); Jackson v. Jackson, supra note 178 .

${ }^{20}$ Welty v. Sparks, I79 Iowa I390, I62 N. W. 6I4 (I9I7) ; Jones v. Jones, supra note 92.

${ }^{20}$ Pooley v. Dutton, supra note 69.

$m$ Wendell v. Brown, I42 Wash. 39x, 253 Pac. 452 (1927).

$\approx$ Adkins v. Brett, 184 Cal. 252, 193 Pac. 251 (1920). 
tical, communications primarily concerned with such alleged acts rather than their effect on the alienated spouse should be wholly excluded. ${ }^{223}$ Thus declarations by the plaintiff's husband as to the identity of the woman with whom he was planning to elope are clearly inadmissible as against the defendant. ${ }^{224}$ Such evidence is obviously prejudicial: it should be limited strictly to its proper functions; but when so limited it seems proper to admit it.

Nevertheless, there is substantial authority to the effect that evidence of such communications between the spouses is inadmissible for any purpose, ${ }^{225}$ even without a statutory exclusion-unless it is fairly to be considered part of the res gesta. ${ }^{226}$ Courts taking this position often assert that such evidence is objectionable both as hearsay and as privileged. ${ }^{227}$ As has been shown, it seems clearly to fall within a well settled exception to the hearsay rule; and the privilege seeems to have no very sensible function in view of the serious marital difficulties which almost invariably exist when an alienation action is brought. But many courts regard such exclusion as a settled rule of the common law which can only be removed by an explicit statute. ${ }^{228}$ The danger of having such declarations warped in the plaintiff's testimony and the seriously prejudicial effect of such evidence is also emphasized by some courts; ${ }^{229}$ but as already pointed out such things may be good reasons for limiting it closely but hardly for wholly excluding it. If all evidence which may conceivably be prejudicial is to be excluded there will be very little left to be admitted.

In alienation cases the time of the events or declarations testified to may become material. Thus some courts exclude evidence of the relationships of the spouses and of the defendant with them prior to the marriage. ${ }^{230}$ The weight of authority seems to be to the contrary, admitting such evidence so far as it seems to be pertinent in explaining what happened after the marriage. ${ }^{231}$ The latter rule seems to be the better one, though undoubtedly evidence of matters prior to the marriage is of less weight than that referring to more recent events.

Again, a number of courts exclude any evidence of the relationship between the spouses after their separation, ${ }^{232}$ at least unless it may fairly

* Preston v. Bowers, 13 Ohio St. I (186r) ; Hillers v. Taylor, I08 Md. 148, 69 At1. 7r5 (Ig08); Paup v. Paup, 208 Iowa 215, 225 N. W. 25I (Ig29).

za Dalton v. Martin, I02 W. Va. 595, I36 S. E. 47 (I927).

200 Humphrey v. Pope, I Cal. App. 374, 82 Pac. 223 (1905); Leucht v. Leucht, I29 Ky. 700, II2 S. W. 845 (I908); Magers v. Magers, I43 Iowa 750, I23 N. W. 330 (I909); Brison v. McKellop, supra note 8o.

208 Higham v. Vanosdol, supra note 189.

er Leucht v. Leucht; Magers v. Magers, both supra note 225.

Watkins v. Lord, supra note II.

$=$ McGowan v. Armour, 248 Fed. 676 (C. C. A. 8th, I9I8).

s30 Pooley v. Dutton, supra note 69; Lonnborg v. Lipset, I37 Misc. 292, 24I N. Y. Supp. 69I (1930).

${ }^{232}$ Cole v. Johnson, supra note 75 ; Spiry v. Spiry, supra note 85 ; Wallace v. Wallace, supra note 97 .

ss Harper v. Harper, supra note I75; Johnson v. Richards, supra note 8. 
be said to constitute a part of the res gesta of the separation. ${ }^{233}$ Here, too, there are contrary authorities holding that the relationship between the spouses after separation may have a bearing upon the cause of the separation and particularly the defendant's relationship to that cause. ${ }^{234}$ It would seem best to treat this problem also as one of judicial discretion. While such evidence is often too remote to have any real pertinency it seems unwise to lay down a flat rule that it will be excluded under all circumstances.

Vermont has a peculiar and seemingly unique rule. This is that all evidence of complaints by the alienated spouse concerning the plaintiff and all activities of any one concerned except the defendant himself are to be excluded if they take place after the defendant has become intimate with the alienated spouse. ${ }^{235}$ The justification given for this peculiar rule is the danger of collusion between the spouses concerned in the alienation action. ${ }^{236}$ It does seem probable that if collusion could be shown that it ought to be a bar even to an alienation action. ${ }^{237}$ Even though one of the spouses is not a party to the action, formally at least, yet both are quite directly interested, and collusion between them might lead to serious injustice to the defendant. On the other hand, there is no such serious danger of collusion as in matrimonial actions or even in actions for criminal conversation; ${ }^{238}$ the alienated spouse is much more likely to have his sympathies with the defendant than with his own present or former spouse, the plaintiff. The Vermont rule therefore seems unsound as an absolute rule of exclusion, though the jury should no doubt be warned of the possibility of collusion between the spouses where there seems to be any substantial reason to fear it.

\section{Damages}

The problem of damages in an alienation suit is a very embarrassing one. As in breach of promise suits ${ }^{239}$ there is no definite standard, and the matter is apt to be left pretty much to the jury, which is entitled to take into consideration many indefinite and purely psychological injuries to which the plaintiff lays claim. ${ }^{240}$ The plaintiff may thus recover damages for his mental suffering and disgrace-and the action is concededly largely of a sentimental nature. ${ }^{241}$ The injury, though not precisely measurable, jus-

Mumper v. Webster, sipra note I89.

$\approx$ Rose v. Mitchell, supra note 218; Puth v. Zimbleman, 99 Iowa 64I, 68 N. W. 895

(I896); Boyd v. Strickland, supra note I65.

Button v. Knight, 95 Vt. 38I, II5 Atl. 499 (192I); Sargent v. Robertson, supra note 62.

${ }_{a \infty 3}$ Fratini v. Caslini, supra note I98; Sargent v. Robertson, supra note 62.

$\infty$ See Olsen v. Erickson, supra note I3I.

$\approx$ Puth v. Zimbleman, supra note 234.

200 See Brown, Breach of Promise Suits (I929) 77 U. of PA. L. Rev. 474, 480.

${ }_{210}$ See Note (1930) 66 A. L. R. 609. See also I3 R. C. L. I481.

as See discussion in Rash v. Pratt, supra note I3I. See also Hartpence v. Rogers, supra note I23; Lyen v. Lyen, supra note I04. 
tifies substantial damages. ${ }^{242}$ Courts admit a certain obligation to prevent undue prejudice in the matter of damages, ${ }^{243}$ but also emphasize the fact that the jury has broad discretion without definite limits. ${ }^{244}$ Courts on appeal often sustain verdicts which they regard as excessive but not sufficiently so to justify interference with the jury's discretion. ${ }^{245}$ Furthermore, as will be considered more in detail hereafter, punitive damages are very generally allowed in alienation suits.

Where a wife is the plaintiff she is entitled to have the jury consider the loss of her husband's support as an additional ground for damages; and this even though he is in fact contributing to her support under the terms of the divorce decree. ${ }^{246}$

Under this situation it is naturally to be expected that verdicts will be large and often much influenced by the feeling of sympathy which the jury is apt to have toward a plaintiff thus wronged. Such is the fact. The largest judgment which has been found in the reports is for $\$ 125,000,{ }^{247}$ but there are several others for substantial amounts up to $\$ I_{5}, 000 .^{248}$ While these verdicts are somewhat larger than the average, they indicate that a defendant who is open to this sort of action is subjecting himself to the possibility of large damages.

The most effective remedy which the defendant has in this matter is the power of the trial judge to reduce damages which he regards as clearly excessive. At times this power is exercised with considerable vigor as in Woodhouse v. Woodhouse, ${ }^{249}$ where a verdict of $\$ 465,000$ was reduced to $\$ 125,000$, and in Overton v. Overton, ${ }^{250}$ where damages of $\$ 150,000$ were reduced to $\$ 60,000$. Generally the reduction is not so great; in fact these are the largest reductions found, but substantial reductions are not uncommon. ${ }^{251}$ In all these cases, however, there is still left a substantial amount which the defendant is required to pay.

${ }_{212}$ Valentine v. Pollak, supra note $\mathrm{I}$.

${ }_{223}$ Nicholson v. Nicholson, 22 S. W. (2d) 514 (Tex. Civ. App. I929).

24 Fuller v. Robinson, supra note I7I.

${ }_{245}$ Amellin v. Leone, supra note 132.

2s6 Allard v. LaPlain, I25 Me. 44, I30 At1. 737 (I925). In the Washington case of the same name, supra note 7 , suit was brought on this judgment in that state.

${ }_{247}$ Woodhouse v. Woodhouse, supra note 92 . This case has also a rather distinct and unregrettable uniqueness in having a total of IOI headnotes. This judgment, and most of the others cited in this connection, included punitive damages.

${ }_{2 s 8}$ Mohn v. Tingley, supra note 29 (\$100,000) ; Mulock v. Ulizio, 3 N. J. Misc. 63I, 129 At1. 204 (I925) (\$25,000); Bradbury v. Brooks, supra note I3 (\$25,000); Lyen v. Lyen, supra note I04 (\$15,000); Hollinghausen V. Ade, supra note 32 (\$15,000); McAllister v. McAllister, supra note 68 (\$I 5,000$)$.

219 Supra note 92.

${ }^{200}$ Supra note I33.

201 Regenvetter v. Ball, I3I Wash. I55, 229 Pac. 32I (I924) (\$27,500 reduced to \$20,000); Lanigan v. Lanigan, supra note 25 (\$22,500 reduced to $\$ 10,000)$; Peak v. Rhyno, supra note I55 (\$16,750 reduced to $\$ 8,000)$. 
In a few cases a verdict in favor of the plaintiff has been reversed because of excessive damages. ${ }^{252}$ This happens comparatively rarely, and usually only when there is fairly definite evidence indicating that damages should be small. On the other hand, there are several cases where a judgment for merely nominal damages has been reversed on the ground that nominal damages are inadequate. ${ }^{253}$ Where a plaintiff proves a cause of action for alienation of affections the situation invariably justifies and even requires substantial damages. ${ }^{254}$

Apart from all this, as has already been indicated, punitive damages are almost invariably allowed. In view of the obvious vagueness of the basis for computing compensatory damages it clearly follows there is no definite line between compensatory and punitive damages in this sort of action; in fact it has been stated with much apparent reason that damages in an action for alienation of affections are almost entirely punitive. ${ }^{255}$ However this may be, most authorities avowedly permit punitive damages in this sort of case. $^{256}$ Quite naturally courts will decline to interfere on the basis of the amount of the verdict when it seems that punitive damages are allowable even though the amount of the verdict is clearly excessive in so far as compensatory damages are concerned. ${ }^{257}$ It seems that punitive damages need not be claimed by the plaintiff in his pleading. ${ }^{258}$

However, to justify an award of punitive damages, malice in its strict sense, or at least a wanton disregard of the plaintiff's rights, must be shown. ${ }^{259}$ This is, of course, not properly required for merely compensatory damages. The malice or wantonness may be shown by indirect and circumstantial evidence; and a mere showing of deliberate action by the defendant may sometimes be sufficient for this purpose. ${ }^{260}$

It has been held that no punitive damages can be awarded unless there are actual damages ${ }^{261}$ that is to say, there must be substantial compensatory damages as a prerequisite for the award of punitive damages. However, a New York court has allowed punitive damages in a case where only nominal

$\approx 2$ Okrent v. Raffa, sutra note 73 ; Sivley v. Sivley, 96 Miss. 137, 5 I So. 457 (1910); Allen v. Rossi, I28 Me. 20I, I46 Atl. 692 (1929); Scharwath v. Brooks, I45 Atl. 727 (N. J. I929). note $\mathrm{I}$.

Bracken v. Champlin, II4 Kan. 882, 220 Pac. I027 (I923) ; Riggs v. Smith, supra

$\approx$ See Valentine v. Pollak, supra note I.

$\approx$ See (Igr8) 6 CALIF. L. Rev. 379.

wos Warner v. Miller, supra note 58; Woodhouse v. Woodhouse, supra note 92 ; Hollinghausen v. Ade, sutpra note 32 ; Oskamp v. Oskamp, 20 Ohio App. 349, I52 N. E. 208 (I925); Harlow v. Harlow, supra note 75; Rash v. Pratt, supra note I3I.

$\approx \pi$ Rockwell v. Rockwell, supra note 66.

${ }^{203}$ Joseph v. Naylor, supra note 15.

sos Button v. Knight, supra note 235; Cottle v. Johnson, supra note 204; Kleber v. Allin, supra note 61 .

$2 \infty$ Butterfield v. Ennis, supra note 33 ; Bradbury v. Brooks, supra note I3.

201 Gilham v. Devereaux, 67 Mont. 75, 214 Pac. 606 (I923). 
compensatory damages ( $\$ I$ ) were awarded, ${ }^{262}$ the court saying that the jury evidently thought that the wife (the alienated party) had little affection for her husband but nevertheless desired to punish the defendant for his "disregard of the marital relationship in its aspect of menace to the community". Assuming that punitive damages can be justified in any case-a problem beyond the scope of this article-the latter decision seems justified.

When punitive damages are properly awardable, the decided weight of authority permits evidence of the defendant's wealth, ${ }^{263}$ but on this issue alone. $^{264}$ This is obviously justifiable, since the adequate punishment of a wealthy person will obviously require much higher damages than if he were comparatively poor. If there is more than one defendant it would appear that evidence of wealth of any one of them would be inadmissible against the others and that therefore punitive damages would in such a case be unrecoverable $;^{265}$ but there is authority to the contrary. ${ }^{266}$ On the other hand, proof that the defendant has little wealth is not absolutely conclusive against the awarding of punitive damages; as one court puts it, he still may have prospects. ${ }^{267}$ But it would seem that considerable leniency should be shown in the amount of punitive damages in such a case.

In this whole matter of punitive damages this action has a very close analogy to the action for breach of promise of marriage. ${ }^{268}$ Unfortunately, this analogy is carried so far as to follow the peculiar rules governing proof of the defendant's wealth in breach of promise actions. Thus the plaintiff may prove the defendant's reputation for wealth and thereby subject him to having the damages computed on what people suppose him to have rather than what he actually has. ${ }^{269}$ This unjust result is partially remedied by the illogical rule that the defendant may rebut such evidence of his reputed wealth by showing what property he actually has ${ }^{270}$-again following the unfortunate analogy of breach of promise suits.

A few courts which do admit punitive damages in this sort of action nevertheless refuse to admit evidence of the defendant's wealth. ${ }^{271}$ This doctrine seems less logical in view of the fact that the defendant's wealth is

$s$ Buteau v. Naegeli, supra note I30. The Appellate Division reduced the judgment from $\$ 5,000$ to $\$ 1,218.76$, but wrote no opinion. Obviously this is still a substantial judgment for punitive damages.

${ }^{003}$ See 13 R. C. L. I475. See also Johnson v. Allen, supra note 136; Hargraves v. Ballou, supra note IO.

os Allard v. LaPlain, supra note 246; Ramsey v. Ramsey, supra note Ior.

$\approx$ Leavell v. Leavell, II4 Mo. App. 24, 89 S. W. 55 (Ig05).

${ }^{\infty}$ See Oskamd v. Oskamp, supra note 256 . See also White v. White, supra note 43.

Hargraves v. Ballou, supra note Io.

See Brown, supra note 239.

${ }^{209}$ Leavell v. Leavell, supra note 265 , holding however that evidence of the actual wealth of the defendant may be shown on the issue of punitive damages-though not on the issue of compensatory damages.

${ }_{20}$ Hargraves v. Ballou, supra note 10.

znt Stanton v. Cox, 162 Miss. 438 , I39 So. 458 (1932). See also Jenness v. Simpson, supra note I. 
certainly a pertinent circumstance in connection with the amount of punitive damages; but the absurd way in which the courts permit such wealth to be proved and disproved gives a certain practical justification for the narrow rule laid down by these courts.

A rather curious situation arises with respect to punitive damages in actions against parents and other close relatives. It would seem that since such relatives can only be held liable if they are guilty of actual malice, the mere fact of their being held at all would necessarily subject them to liability for punitive damages. In other words, the very malice which subjects them to any liability also subjects them to punishment by way of punitive damages. This is frankly avowed by the Supreme Court of North Dakota ${ }^{272}$ and the same result seems to be reached in several other cases where a relative entitled to the favorable presumption already discussed, but held liable because of his malice, was held also to have been properly compelled to pay punitive damages. $^{273}$ The possible objection to this is that it puts parents and other close relatives on a worse footing as to punitive damages than other persons; but this difficulty is theoretical rather than practical, since the parent's liability to pay punitive damages results immediately from his freedom from liability to pay any damages at all in many situations where an outsider would be so liable.

Several courts deny punitive damages in alienation cases in toto. ${ }^{274}$ However, most if not all of these courts do not permit punitive damages in any sort of case ${ }^{2 \pi 5}$ so that the disallowance in alienation cases is not peculiar to that kind of action.

\section{Equitable Relief and Miscellaneous}

In view of the nature of an alienation suit, particularly the rather indefinite but largely personal measure of the wrong, it would seem that compensatory damages are ordinarily an inadequate remedy and that even punitive damages, when allowed, will not adequately compensate the plaintiff for what he has lost. From this standpoint it would appear that where the plaintiff acts soon enough, he ought to be entitled to relief by having the defendant enjoined from acting in such a way as to deprive the plaintiff of his right of consortium. There has been a considerable amount of discussion

$2 \mathrm{mos}$ Oster v. Oster, 49 N. D. 723, I93 N. W. 3 I6 (I923).

${ }_{2 \pi 3}$ Moelleur v. Moelleur, supra note 60; Harlow v. Harlow, supra note 75 ; Allen v. Rossi, supra note 252 .

274 Moulin v. Monteleone, supra note 27 (see discussion of the Louisiana law in that note) ; French v. Deane, I9 Colo. 504, 36 Pac. 609 (1894) (now allowed in Colorado, by statute); Sohl v. Sohl, II4 Neb. 353, 207 N. W. 669 (I926); Phillips v. Thomas, 70 Wash. 533, I27 Pac. 97 (I912); Wood v. Miller, I47 Wash. 25I, 265 Pac. 727 (1928).

2ro Washington may be an exception to this rule, the court indicating that the denial of punitive damages is applicable only in alienation suits. Phillips v. Thomas, supra note 274 . 
of this problem by legal theorists ${ }^{276}$-more perhaps than the amount of actual case material. It seems to be generally agreed that equity has jurisdiction, because of the obvious inadequacy of the legal remedy of damages; but there is serious question as to whether such jurisdiction should be exercised, both because of the difficulty of enforcing any orders which the court may make and because of the inherent undesirability of trying to arrange domestic controversies through the rather crude medium of injunctions.

Texas ${ }^{277}$ has squarely taken the position that an injunction will be granted in a case where the plaintiff shows a deliberate and continuing attempt by the defendant to deprive the former of his rights of consortium. There is a dictum to the same effect in a decision by one of the lower New York courts. ${ }^{27 s}$

On the other hand, Ohio has in a very well considered opinion taken the opposite view, holding that in no circumstance has equity jurisdiction to give an injunction in such a case. ${ }^{279}$ The dissenting opinions seem to be much better reasoned than the majority opinion, ${ }^{280}$ but even the dissenting judges are constrained to admit that such jurisdiction is somewhat dangerous and should be sparingly exercised. The very scarcity of decisions on the point indicates that equitable relief in this sort of action has little if any scope in most jurisdictions. Problems of enforceability and public policy seem to require that this matter be settled, even though somewhat inadequately, by ordinary suits for money damages.

Two cases have been found which involve something of a reversal of the ordinary situation in alienation suits. One of these is Swartzlander $v$. Swartzlander, ${ }^{281}$ where the husband sued a third person for the alienation of his wife and was successful. He assigned the judgment to two other persons. The wife now sues to subject the judgment in the hands of the assignees to the husband's liability on a separation agreement. This ingenious scheme was, however, defeated by the court; it was held that the wife was barred by her own wrongdoing (in being alienated) even though the husband acted improperly in assigning the judgment.

A still more curious situation appears in Work $v$. Campbell. ${ }^{282}$ Here the wife sued the husband of her own aunt alleging that the defendant told her lies about her (the plaintiff's) husband, thus causing the plaintiff to treat

${ }_{2 \pi 6}$ The most detailed discussion of the general subject is in Moreland, Injunctive Control of Family Relations (1930) I8 Ky. L. J. 207. See also Notes in (1925) 25 CoL. L. Rev. 373; (I925) 34 YaLE L. J. 327 ; (1925) 38 HARV. L. REv. 396; (I925)' 74 U. OF PA. L. REv. 97.

${ }_{2 m}$ Ex parte Warfield, 40 Tex. Cr. App. 4I3, 50 S. W. 933 (I899); Smith v. Womack, 27I S. W. 209 (Tex. Civ. App., 1925).

æis See Hall v. Smith, 80 Misc. 85 , I40 N. Y. Supp. 796 (I913). Such an injunction was disallowed on the facts in Ellis v. Ellis, 55 Misc. 34, 106 N. Y. Supp. 217 (1907).

${ }_{279}$ Snedaker v. King, III Ohio St. 225, I45 N. E. I5 (I924).

200 The majority opinion was "per curiam", though there was a concurring opinion by Justice Allen. Justice Day wrote the most forceful dissenting opinion.

ess I27 Misc. 801, 2I7 N. Y. Supp. 467 (1926).

202 I64 Cal. 343, I28 Pac. 943 (I912). 
her husband so cruelly that he left her. The theory of the action was not entirely clear to the court, but it decided, it seems quite correctly, that no cause of action for alienation or enticement of the husband was shown; the court suggested that the husband could probably sue the defendant for the enticement of the wife, the present plaintiff. There was a dictum, however, that the plaintiff did show a cause of action for deceit. This is the only case which has been found where what was alleged to be an alienation suit was brought by the alienated spouse.

\section{Policy of the Action}

It remains to consider whether the action for alienation of affections is a desirable one. This involves a consideration of the problem as to whether the action performs a useful social function and, if it does, whether there may not still be such serious objections to it as to make its abolition desirable.

Taking up this latter problem first, it is clear that there are in fact serious objections to the action. The most obvious one is the uncertain basis for the damages and the fact that such damages are largely punitive. ${ }^{283}$ Even when they purport to be compensatory, the measure of damages is so uncertain as to result quite clearly in occasional and perhaps quite serious injustice to the defendant.

It is also urged that a consideration of the history of the action shows that it has no proper place in our modern law. ${ }^{284}$ Undoubtedly the action for alienation of affections as well as that for criminal conversation originated in the husband's power over the wife and was therefore originally restricted to the husband alone. It is therefore argued that the wife's emancipation, which takes away the original basis for both of these actions, should have resulted in their total abolition. But this is an obvious non sequitur since the abolition of the original basis for the action does not necessarily prove that it has not still justification under modern conditions.

Another objection, though one of a theoretical rather than practical nature, is the difficulty of defining the wrong precisely. As has been seen, the courts are not entirely clear as to whether this is a personal tort or one to property. ${ }^{285}$ This theoretical uncertainty is not of itself serious, but does indicate that the action should be somewhat closely restricted. ${ }^{286}$ The frequent use of the action for purposes of extortion ${ }^{287}$ emphasizes this objection.

In spite of all these and other objections which could no doubt be suggested, it is submitted that the action is still justifiable and performs a useful

¿ss Supra note 255 .

si See Lippman, The Breakdozen of Consortium (I930) 30 CoL. L. Rev. 651.

cos Supra note 255 .

${ }^{25 s}$ See (Ig28) 4I HaRv. L. REv. 535.

as Miller v. Levine, supra note 85 . 
social function. That function is the preservation of the home. No one can doubt that the American home is by no means stable in these days, and very few would doubt that any influence, legal or otherwise, which would increase its stability is to be encouraged. ${ }^{2 s s}$ The problem of policy has been before the English courts very clearly in the recent case of Place v. Searle, ${ }^{289}$ where the court, reversing the opinion of the redoubtable Justice McCardie to the contrary, held that the emancipation of women has had no effect upon the action for alienation of affections. Each spouse still has a right of consortium in the other, though our modern statutes have radically and properly limited the husband's power to enforce such rights directly against his wife. The American courts are undoubtedly following the same idea, though generally without passing so explicitly upon the question of policy.

The only real argument which can be made that the action is harmful is because of the possible injustice to the defendant. But it seems that such a defendant is not entitled to overmuch sympathy. If he is to be held at all he must be shown to have intentionally interfered in the marital relations of another person; in other words, he has intentionally attempted to break up some one else's home, and has had at least a measure of success. If the uncertainty of the damages will terrify some persons, who otherwise would be guilty of such a thing, from attempting it, that is all the better. Further, if the defendant is a parent or other near relative of one of the spouses and honestly believes that the protection of that spouse requires the termination of the marital relations, he can act without serious fear of the consequences; for it is believed that not merely the holdings of the courts but also the opinions of juries are generally very favorable to such relatives, unless there is fairly clear evidence that the alienation was not the result of proper motives. With all its faults, then, the action for alienation of affections is on the whole desirable, and while it should no doubt be somewhat limited, such limitations should not be permitted to diminish the desirable effect which the possibility of liability in this action now has in discouraging the intentional breaking up of homes.

See Holbrook, The Change in the Meaning of Consortium (1923) 22 MICH. L. REv. I. See also the dissenting opinion in Bourne v. Bourne, supra note 48 , at 535,185 Pac. at 497.

${ }_{0 s 0}$ [1932] 2 K. B. 497. The upper court held clearly that the old case of Winsmore v. Greenback, supra note I, still represents the law of England. 